\title{
Source identification and airborne chemical characterisation of aerosol pollution from long-range transport over Greenland during POLARCAT summer campaign 2008
}

\author{
J. Schmale ${ }^{1}$, J. Schneider ${ }^{1}$, G. Ancellet ${ }^{2}$, B. Quennehen ${ }^{3}$, A. Stohl ${ }^{4}$, H. Sodemann ${ }^{4,5}$, J. F. Burkhart ${ }^{4,6}$, T. Hamburger ${ }^{7}$, \\ S. R. Arnold ${ }^{8}$, A. Schwarzenboeck ${ }^{3}$, S. Borrmann ${ }^{1,9}$, and K. S. Law ${ }^{2}$ \\ ${ }^{1}$ Max Planck Institute for Chemistry, Mainz, Germany \\ ${ }^{2}$ UPMC Univ. Paris 06, Univ. Versailles St-Quentin, CNRS/INSU, LATMOS-IPSL, Paris, France \\ ${ }^{3}$ Laboratoire de Météorologie Physique, Université Blaise Pascal, Aubière, France \\ ${ }^{4}$ Norwegian Institute for Air Research, Kjeller, Norway \\ ${ }^{5}$ ETH Zürich, Institut für Atmosphäre und Klima, Zürich, Switzerland \\ ${ }^{6}$ School of Engineering, University of California, Merced (UCM), Merced, CA, USA \\ ${ }^{7}$ Deutsches Zentrum für Luft und Raumfahrt, Institut für Physik der Atmosphäre, Oberpfaffenhofen, Germany \\ ${ }^{8}$ Institute for Climate and Atmospheric Science, School of Earth and Environment, University of Leeds, UK \\ ${ }^{9}$ Institute for Atmospheric Physics, Johannes Gutenberg University, Mainz, Germany
}

Received: 7 February 2011 - Published in Atmos. Chem. Phys. Discuss.: 4 March 2011

Revised: 19 August 2011 - Accepted: 27 September 2011 - Published: 6 October 2011

\begin{abstract}
We deployed an aerosol mass spectrometer during the POLARCAT (Polar Study using Aircraft, Remote Sensing, Surface Measurements and Models, of Climate, Chemistry, Aerosols, and Transport) summer campaign in Greenland in June/July 2008 on the research aircraft ATR-42. Online size resolved chemical composition data of submicron aerosol were collected up to $7.6 \mathrm{~km}$ altitude in the region 60 to $71^{\circ} \mathrm{N}$ and 40 to $60^{\circ} \mathrm{W}$. Biomass burning (BB) and fossil fuel combustion (FF) plumes originating from North America, Asia, Siberia and Europe were sampled. Transport pathways of detected plumes included advection below $700 \mathrm{hPa}$, air mass uplifting in warm conveyor belts, and high altitude transport in the upper troposphere. By means of the Lagrangian particle dispersion model FLEXPART, trace gas analysis of $\mathrm{O}_{3}$ and $\mathrm{CO}$, particle size distributions and aerosol chemical composition 48 pollution events were identified and classified into five chemically distinct categories. Aerosol from North American BB consisted of $22 \%$ particulate sulphate, while with increasing anthropogenic and Asian influence aerosol in Asian FF dominated plumes was composed of up to $37 \%$ sulphate category mean value. Overall, it was found that the organic matter fraction was larger
\end{abstract}

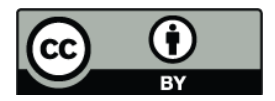

Correspondence to: J. Schmale (julia.schmale@gmail.com)
(85\%) in pollution plumes than for background conditions $(71 \%)$. Despite different source regions and emission types the particle oxygen to carbon ratio of all plume classes was around 1 indicating low-volatility highly oxygenated aerosol. The volume size distribution of out-of-plume aerosol showed markedly smaller modes than all other distributions with two Aitken mode diameters of 24 and $43 \mathrm{~nm}$ and a geometric standard deviation $\sigma_{\mathrm{g}}$ of 1.12 and 1.22 , respectively, while another very broad mode was found at $490 \mathrm{~nm}\left(\sigma_{\mathrm{g}}=2.35\right)$. Nearly pure BB particles from North America exhibited an Aitken mode at $66 \mathrm{~nm}\left(\sigma_{\mathrm{g}}=1.46\right)$ and an accumulation mode diameter of $392 \mathrm{~nm}\left(\sigma_{\mathrm{g}}=1.76\right)$. An aerosol lifetime, including all processes from emission to detection, in the range between 7 and 11 days was derived for North American emissions.

\section{Introduction}

After the discovery of haze layers in late winter and early spring in the lower Arctic atmosphere by pilots overflying Canada and Alaska in the 1950s (Greenaway, 1950; Mitchell, 1956) numerous campaigns and continuous measurements of Arctic aerosol have been conducted (Rahn et al., 1977; Schnell, 1984; Shaw, 1995; Law and Stohl, 2007; Quinn et al., 2007, and references therein). However, Arctic aerosol

Published by Copernicus Publications on behalf of the European Geosciences Union. 
research has focused predominantly on winter/spring (Rahn and McCaffrey, 1980; Shaw, 1995; Stohl et al., 2006) while fewer measurements have been performed during summer when concentrations are generally lower (Law and Stohl, 2007). Most of the available in-situ measured aerosol data (optical, microphysical, and chemical) have been collected at the surface, whereas only very few summertime airborne studies of aerosol chemical composition have been carried out so far (Brock et al., 1989, 1990; Talbot et al., 1992; Franke et al., 1997; Dreiling and Friederich, 1997). In summer 2008, the NASA ARCTAS (Arctic Research of the Composition of the Troposphere from Aircraft and Satellites, Jacob et al., 2010) and POLARCAT-France (Polar Study using Aircraft, Remote Sensing, Surface Measurements and Models, of Climate, Chemistry, Aerosols, and Transport) campaigns in June/July 2008 deployed aerosol mass spectrometers (AMS) for non-refractory submicron aerosol detection together with other aerosol and trace gas related instrumentation.

In contrast to Arctic air pollution in winter and early spring, when weather conditions are more stable and particulate matter can remain suspended in the Arctic troposphere for up to several weeks, summertime pollution is subject to more varied weather conditions (Shaw, 1995; Stohl, 2006). Wet deposition partly prevents aerosol from reaching high northern latitudes, especially with regard to Asian air masses entering the Arctic with the Pacific storm track (Park et al., 2005; Dickerson et al., 2007; Matsui et al., 2011). Nevertheless, there are several source regions, North America (NA), Europe, Siberia, and East Asia, from where pollution plumes are transported towards the Arctic (e.g. Rahn, 1977; Koch and Hansen, 2005; Stohl, 2006; Stohl et al., 2006; McConnell et al., 2007; Shindell et al., 2008). The main emission sources are biomass burning (BB) and fossil fuel combustion (FF) including smelter emissions, e.g. from Norilsk or the Kola peninsula. Anthropogenic activity can be assumed to be a relatively predictable source of emissions as changes are driven primarily by industrial and economic development and environmental legislation (Lavoue et al., 2000; McConnell et al., 2007). BB emissions, however, vary substantially from year to year. Boreal forest fires are ignited both naturally by lightning and by humans (Flannigan et al., 2009). However, while the number of human induced fires is greater, large fires are more often caused by lightning (Stocks et al., 2002). During summer 2008, extensive boreal forest fires occurred in eastern Siberia in the Yakutsk region, and there was elevated fire activity in Saskatchewan, Canada, (Jacob et al., 2010; Paris et al., 2009; Singh et al., 2010), both influencing the atmospheric composition in the Arctic.

Due to the sulphur content in fossil fuels, FF is associated with the formation of particulate sulphate from $\mathrm{SO}_{2}$ emissions, while biomass burning emissions have a low sulphur content (Andreae and Merlet, 2001). Both sources emit gasphase and particulate organic compounds which contribute to carbonaceous particulate matter in the pollution plumes either directly or by gases partitioning into the particle phase (Donahue et al., 2009). Thus, when characterising the source type of a pollution plume, rather low particulate sulphate but high organic carbon fractions are expected for BB plumes (Reid et al., 2005; Singh et al., 2010), whereas for FF the sulphate contribution is expected to be elevated (Heald et al., 2008; Singh et al., 2010). Because of the long transport times of up to more than two weeks the aerosol arriving over Greenland is expected to be highly oxygenated due to chemical ageing (Jimenez et al., 2009) as confirmed by surface measurements of $\mathrm{PM}_{2.5}$ chemical composition at Summit, central Greenland (von Schneidemesser et al. 2009; Hagler et al. 2007). Thus, properties such as optical behaviour, hydrophobicity/hygroscopicity and size distributions are expected to be different from near source aerosol. Understanding of the chemical composition and state of oxidation of particulate matter is important for modelling its impacts on the Arctic system, one of the most sensitive regions on Earth in terms of climate change (IPCC, 2007). Aerosol directly influences atmospheric radiative transfer via its optical properties and indirectly via aerosol cloud interactions. Depending on the composition particulate matter preferentially absorbs (black carbon) or scatters (sulphate) radiation. Deposited aerosol can change the surface albedo of snow or ice (Quinn et al., 2008), leading to enhanced surface warming and melting, and can contribute to the acidification of the Arctic (AMAP, 2006).

In summer, pollution plumes reach the Arctic troposphere by a number of different transport patterns depending on their source region: low-level transport below $800 \mathrm{hPa}$, low-level transport with subsequent ascent, and higher altitude transport above $600 \mathrm{hPa}$ (Stohl, 2006). Air masses over central Greenland especially follow the second and third pathways (Hirdman et al., 2010), due to the elevation of the ice sheet $(>3.2 \mathrm{~km})$. However, it must be taken into consideration that low-level transport to the Arctic is nearly absent during summer and that the Arctic front retreats far North during this time of year so that the sampled air masses were not always of true Arctic character. Air mass uplift, partly with strong ascent rates, takes place in the warm conveyor belt (WCB) of synoptic low pressure systems (Browning et al., 1982; Cooper et al., 2002). In the region of the North Atlantic and Pacific storm tracks this mechanism can enhance longrange export of polluted air masses from the industrialised areas of eastern US and East Asia (Stohl, 2001; Dickerson et al., 2007). Observational evidence suggests that transport in WCBs partly but not completely removes aerosol by wet deposition (Park et al., 2005).

In this paper we present the chemical composition and origin of submicron aerosol in the free troposphere over Greenland measured by an aircraft-based Aerodyne aerosol mass spectrometer (AMS) during the POLARCAT-France experiment in June/July 2008. Air masses were intercepted while entering or leaving the Arctic. The main objective of the AMS deployment was the study of individual polluted 
long-range transport air masses, the identification of emission source regions and their associated aerosol chemical characteristics, as well as particle lifetimes and size distributions.

\section{Background of the POLARCAT campaign and in-situ instrumentation}

The POLARCAT-France summer campaign was carried out from 30 June to 14 July, 2008, as part of the International Polar Year initiatives. The Safire (Service des Avions Français Instrumentés pour la Recherche en Environnement) research aircraft ATR-42 was based in Kangerlussaq $\left(67.0^{\circ} \mathrm{N}, 50.7^{\circ} \mathrm{W}\right)$, Greenland, from where all scientific flights were conducted between 60 to $71^{\circ} \mathrm{N}$ and 40 to $60^{\circ} \mathrm{W}$. Submicron aerosol chemical composition measurements were performed with a unit mass resolution Aerodyne aerosol mass spectrometer (AMS) which operated successfully during eight flights. Further instruments aboard the ATR-42 are listed in Table 1. The flight tracks are shown in Fig. 1. The maximum altitude ceiling was $7.6 \mathrm{~km}$, the speed $100 \mathrm{~m} \mathrm{~s}^{-1}$ and the maximum flight duration three hours. Data with temporal resolution of $1 \mathrm{~s}$ thus represent a horizontal resolution of $100 \mathrm{~m}$ and $2 \mathrm{~min}$ average data $12 \mathrm{~km}$. The vertical resolution during ascents and descents is approximately $5 \mathrm{~m}$ and $600 \mathrm{~m}$, respectively. The main purpose of the AMS deployment within the scope of the POLARCATFrance study was the identification and chemical characterisation of particulate matter in long-range transport pollution plumes originating from different source regions and emission sources.

\subsection{Aerosol mass spectrometer}

The chemical composition, mass concentration and size distribution of submicron aerosol was determined by a Compact Time-of-Flight Aerosol Mass Spectrometer (C-ToF-AMS, hereafter AMS) (Drewnick et al., 2005; Canagaratna et al., 2007). In short, aerosol is sampled through a critical orifice placed in front of an aerodynamic lens which focuses the particles into a narrow beam. The particle beam is cut and blocked periodically by a chopper before it enters a time-offlight region in a vacuum chamber where particles are concentrated and accelerated, which allows for particle sizing in terms of vacuum aerodynamic diameter $\left(d_{\mathrm{va}}\right.$, DeCarlo et al., 2004). Subsequently, the particulate matter is flash-vaporised by a $600{ }^{\circ} \mathrm{C}$ heater and the vapour is ionized by electron impact $(70 \mathrm{eV})$. The ions are extracted into a time-of-flight mass spectrometer. By subtracting the instrument's background signal, measured when the chopper is blocking the particle beam, from the aerosol signal and by means of a fragmentation table (Allan et al., 2004b) the obtained mass spectra can be converted into particulate mass concentrations of the following chemical species: ammonium, nitrate, sulphate, or-

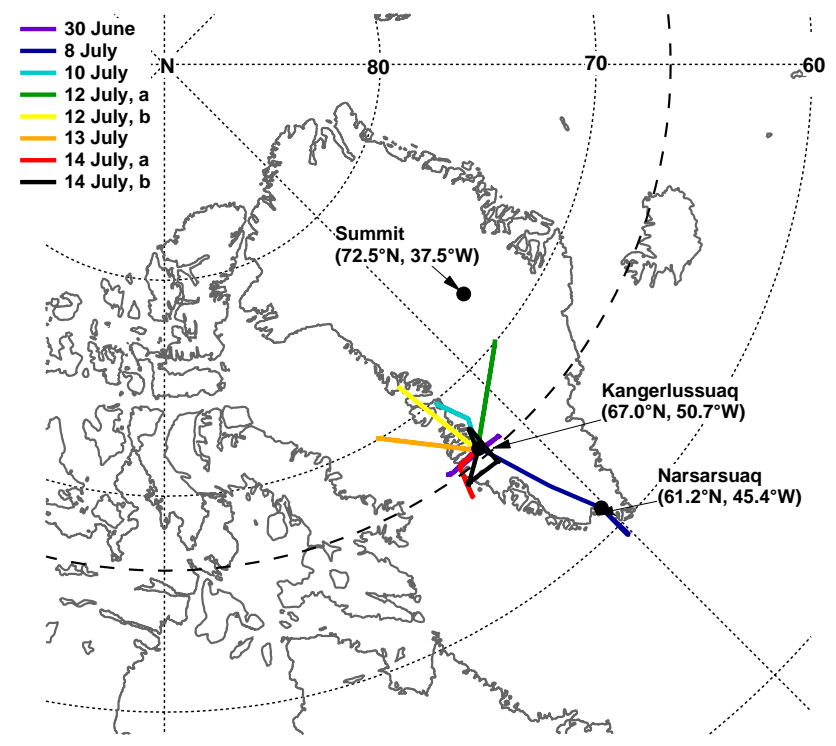

Fig. 1. POLARCAT-France summer experiment 2008 flight tracks involving AMS measurements covering altitudes from sea level to $7.6 \mathrm{~km}$. The research aircraft, ATR-42, was based in Kangerlussuaq, Greenland.

ganics, and chloride. Here, we focus on mass concentrations of sulphate and organics as the other species were usually below the detection limit. The AMS was operated in the socalled general alternation mode recording mass spectra for five seconds and subsequently particle time of flight equally for five seconds. Three repetitions of this recording were averaged to one data point representing $30 \mathrm{~s}$ of measurements. For final data analysis four points were averaged to two minutes time resolution data. The instrument's ionization efficiency was calibrated six times and the particle time of flight twice during the campaign.

\subsubsection{Inlet system}

Due to changes in ambient pressure during aircraft measurements a pressure controlled inlet system (PCI) was employed (Bahreini et al., 2008). The PCI is designed to keep the pressure in front of the AMS inlet constant to guarantee stable inlet transmission efficiency and stable conditions for particle sizing. The PCI design for the ATR-42 aircraft has been described and characterised in Schmale et al. (2010). The transmission efficiency is $100 \%$ for particles in the range between 200 and $400 \mathrm{~nm} d_{\text {va }}$, while it increases steadily from 20 to $100 \%$ between 80 and $200 \mathrm{~nm}$ and drops to $50 \%$ near $450 \mathrm{~nm}$ from where it decreases to $20 \%$ at $1000 \mathrm{~nm}$. The overall transmission efficiency over the complete transmission range of 80 and $1000 \mathrm{~nm}$ is $54 \%$. The vacuum aerodynamic diameter is denoted by $d_{\mathrm{va}}$ which is equal to the product of the mobility diameter $\left(d_{\text {mob }}\right)$ with the "Jayne shape factor" and the particle density divided by unit density (DeCarlo, 2004). 
Table 1. Instrumentation aboard the ATR-42 during the POLARCAT-France summer campaign 2008.

\begin{tabular}{ll}
\hline Instrument & Reference \\
\hline Compact time-of-flight aerosol mass spectrometer (C-ToF-AMS)* & $\begin{array}{l}\text { Drewnick et al. (2005), Canagaratna et al. (2007), } \\
\text { Schmale et al. (2010) }\end{array}$ \\
Scanning mobility particle sizer (SMPS)* & Villani et al. (2007), Quennehen et al. (2011) \\
Optical particle counter (OPC), GRIMM, model 1.108 & Quennenhen et al. (2011) \\
Nephelometer, TSI, 3563 & Voigt et al. (2010) \\
2D-Cloud probe & Febvre et al. (2009) \\
Passive cavity aerosol spectrometer probe (PCASP), DMT, 100-X & Quennenhen et al. (2011) \\
Particle soot absorption photometer (PSAP) & Bond et al. (1999) \\
Leandre New Generation Aerosol lidar* & de Villiers et al. (2010) \\
Forward scattering spectrometer probe, FSSP 100 & Gayet et al. (2006) \\
IR absorption carbon monoxide detection instrument* & Nedelec et al. (2003) \\
Ozone lidar & Ancellet and Ravetta (2003) \\
UV absorption ozone detection instrument* & Ancellet et al. (2009) \\
Lyman-Alpha hygrometer* & Buck (1976) \\
\hline
\end{tabular}

* Instruments marked with an asterisk contributed to the analysis for this paper.

Table 2. Flight dates and altitude range covered by AMS measurements. Representation of total organic mass spectrum by the selection of organic $\mathrm{m} / \mathrm{z}$ (\% mass), Pearson correlation coefficient $(R)$ of the linear regression, and average 2 min 3 sigma limit of detection (LOD) for each flight.

\begin{tabular}{lrrrrrrrr}
\hline & & & & \multicolumn{3}{c}{2 min LOD $\left(\mu \mathrm{g} \mathrm{m}^{-3}\right)$} \\
\cline { 7 - 10 } 2008 & $\begin{array}{r}\text { covered } \\
\text { Flight Date }\end{array}$ & & & & & Number of \\
altitude $(\mathrm{km})$ & \% mass & $R$ & Pata points & $\begin{array}{r}\text { Particulate } \\
\text { sulphate }\end{array}$ & $\begin{array}{r}\text { Particulate } \\
\text { organics }\end{array}$ & $\begin{array}{r}\text { Particulate } \\
\text { nitrate }\end{array}$ & $\begin{array}{r}\text { Particulate } \\
\text { ammonium }\end{array}$ \\
\hline 30 June & $0-5.5$ & 38 & 0.82 & 32 & 0.08 & 0.80 & 0.03 & 0.35 \\
8 July & $0-7.6$ & 49 & 0.72 & 165 & 0.06 & 0.22 & 0.02 & 0.27 \\
10 July & $0-7.3$ & 47 & 0.80 & 107 & 0.03 & 0.18 & 0.01 & 0.18 \\
12 July, a & $0-6.7$ & 52 & 0.62 & 163 & 0.03 & 0.21 & 0.01 & 0.20 \\
12 July, b & $0-6.7$ & 60 & 0.75 & 145 & 0.04 & 0.23 & 0.02 & 0.25 \\
13 July & $0-7.3$ & 52 & 0.73 & 121 & 0.10 & 0.53 & 0.04 & 0.41 \\
14 July, a & $0-4.6$ & 49 & 0.68 & 145 & 0.08 & 0.25 & 0.02 & 0.18 \\
14 July, b & $0-7.3$ & 43 & 0.74 & 124 & 0.05 & 0.42 & 0.03 & 0.35 \\
\hline
\end{tabular}

Together with the scanning mobility particle sizer (SMPS) and optical particle counter (OPC), see Table 1, the AMS sampled from the community aerosol inlet (CAI) through a $1 / 4^{\prime \prime}$ outer diameter stainless steel tube of approximately $2 \mathrm{~m}$ length. CAI is an isokinetic and isoaxial inlet identical to the University of Hawaii NASA DC-8 aircraft inlet. The 50\% cut-off is at $4.1 \mu \mathrm{m}$ aerodynamic diameter, thus not impairing AMS measurements (McNaughton et al., 2007).

\subsubsection{Data preparation and error estimation}

Due to very low mass concentrations (average of $0.54 \mu \mathrm{g} \mathrm{m}^{-3}$ ) during the POLARCAT-summer experiment many of the mass to charge ratios $(\mathrm{m} / \mathrm{z})$ contributing to the organic spectrum were close to or even below zero. This adds noise to the organic signal and increases the limit of detection (LOD). The LOD depends on the instrument's background signal $\left(I_{\mathrm{b}}\right)$ and is calculated from three times the standard deviation of $I_{\mathrm{b}}$ multiplied by the sqrt(2) to account for the noise in the background and measurement signal which are subtracted from each other for the determination of the aerosol mass concentration. Therefore, only a selection of $\mathrm{m} / \mathrm{z}$, i.e. their contributions to the organic mass spectrum, was chosen to represent the total organic mass similar to the jump mass mode (JMS) used for quadrupole AMS data analysis as described by Crosier et al. (2007) and as suggested by Drewnick et al. (2009). The considered mass to charge ratios were derived from an organic mass spectrum obtained during sampling a pollution plume, thus accounting for mass to charge ratios present in the background and pollution events. The final selection criterion was a combination of three factors: 
1. an increased number of points above LOD compared to the total organic mass signal,

2. a maximum ratio of the correlation coefficient (Pearson's $R$ ), from the linear regression of the organic selection versus the total organic spectrum, and the LOD, and

3. the highest representation of mass of the total organic mass after fulfilment of points 1 and 2 .

This method resulted in the selection of five $\mathrm{m} / z(15,29$, 43,44 , and 59) corresponding to the most abundant ions observed that exhibited a clear signature in all flights. Table 2 shows the correlation coefficients, number of data points included, and fraction of mass represented for each flight. Organic aerosol data discussed in this paper is based on the representative mass to charge ratios and has been rescaled using the linear regression of the organic selection versus the total organic spectrum.

To provide quantitative data at standard temperature and pressure (STP) the aerosol mass concentration after standard AMS data analysis had to be converted when using a pressure controlled inlet (PCI). The formula depends on the volume flow into the instrument, the flow parameters of the PCI and the pressure in the PCI (Schmale et al., 2010).

The total error related to each data point is comprised of two types of uncertainties: (1) a statistical error can be attributed to each measurement point based on ion counting statistics (Allan et al., 2003) which is near $30 \%$ for sulphate data points greater than the three sigma LOD and $41 \%$ for organics for $30 \mathrm{~s}$ time resolution. For data points greater than the one sigma LOD the errors are around $40 \%$ and $63 \%$, respectively. These large statistical errors become plausible when considering that the actual detected ion signal from ambient aerosol is only about $100 \mathrm{~Hz}$ higher than the instrument background signal. (2) The systematic error due to the inlet transmission efficiency of the PCI is close to $30 \%$ (Schmale et al., 2010). A second systematic uncertainty is caused by the collection efficiency (CE) as described by Huffman et al. (2005). CE accounts for losses within the standard AMS inlet and lens system, the non-focusing of particularly shaped particles, and the bounce-off from the heater which occurs for certain types of particles. This uncertainty cannot be calculated on a point by point basis but was estimated for the entire campaign. For this study, CE is assumed to be 0.5 due to the lack of comparable aerosol chemical composition measurements. It has been shown in previous studies that a factor of 0.5 represents well the collection efficiency of ambient aerosol (e.g. Allan et al., 2004a; Drewnick et al., 2005; Hings et al., 2007). While very acidic marine, liquid phase, and liquid coated aerosol tends to have a CE factor of one (Quinn et al., 2006; Matthew et al., 2008) we believe that POLARCAT aerosol has different characteristics since on average more than $70 \%$ of the mass is composed of aged organic material and water would partially evaporate in the inlet tubing due to the temperature differences between ambient air and aircraft interior. This temperature difference was $48 \mathrm{~K}$ on average, while the maximum difference was $75 \mathrm{~K}$. Combining the $\mathrm{CE}$ and the transmission efficiency of the PCI results in an overall collection efficiency $\mathrm{CE}_{\mathrm{PCI}}$ of $0.54 \cdot 0.5=0.27 \pm 0.17$.

The method for calculating the LOD is based on a publication by Drewnick et al. (2009), and has been described in Schmale et al. (2010) for the POLARCAT data. In brief, the applied algorithm allows for calculation of the standard deviation of a signal that is a combination of short-scale noise and long-term trend (Reitz, 2011). This is especially useful for aircraft measurement data when time for establishing the instrument's vacuum is limited. Background concentrations become smaller during operation because the vacuum pressure decreases over time. For POLARCAT it was observed that especially the organic $\mathrm{m} / \mathrm{z}$ decreased exponentially during the scientific flights resulting in long-term trends in the AMS background signal. The LOD was calculated for intervals of one hour during each measurement for two minute time resolution data. The averaged LOD for each flight is shown in Table 2 for the species sulphate, organics, nitrate, and ammonium. The signals of nitrate and ammonium were generally below the detection limit of 0.02 and $0.27 \mu \mathrm{g} \mathrm{m}^{-3}$, respectively, for the POLARCAT campaign, thus no data are shown in this paper.

\subsection{Further instruments aboard ATR-42}

The ATR-42 ozone instrument (Ancellet et al., 2009) is based on UV absorption with two cells and has a precision of $2 \mathrm{nmol} \mathrm{mol}^{-1}$ at a time resolution of four seconds. The CO analyser (Nedelec et al., 2003), based on an IR absorption technique, has a precision of $5 \mathrm{nmol} \mathrm{mol}^{-1}$ with a lower detection limit of $10 \mathrm{nmol} \mathrm{mol}^{-1}$.

The aerosol size distribution for particles smaller than $500 \mathrm{~nm}$ mobility diameter was measured by a Scanning Mobility Particle Sizer (SMPS) consisting of a differential mobility analyser (DMA) as described by Villani et al. (2007) and a CPC (TSI model 3010) for particle detection. The SMPS measured continuously at a time resolution of $130 \mathrm{~s}$ (Quennehen et al., 2011).

A Lyman-Alpha hygrometer (Buck, 1976) was used to provide fast response water vapour measurements. A slower response General Eastern 1011B hygrometer designed for airborne applications was mounted in close proximity and used to normalize the Lyman-Alpha signal.

Basic meteorological (pressure and temperature) and aircraft position data are provided by ATR-42 permanently integrated standard instruments. 


\section{Air mass transport modelling}

\subsection{FLEXPART Lagrangian particle dispersion model}

The source-receptor analysis for long-range transport of particle pollution plumes was conducted by using the FLEXPART Lagrangian model (Stohl et al., 2005). The model calculates the dispersion of hypothetical air parcels based on mean winds interpolated from meteorological analysis fields together with random motions representing turbulence and convection. Results discussed here are from runs driven with ECMWF (European Centre for Medium-Range Weather Forecast) analysis data with a horizontal resolution of $0.5^{\circ} \times 0.5^{\circ}$ and 91 vertical model levels at three hour time steps. In addition, FLEXPART was run with GFS (Global Forecast System of NOAA/NCEP) data with a horizontal resolution of $0.5^{\circ} \times 0.5^{\circ}$ and 26 pressure levels in the vertical. These GFS calculations were used to identify possibly problematic cases where ECMWF and GFS results did not agree. All plumes discussed in this paper are represented in the results by both types of input data. The data are available at http://zardoz.nilu.no/ andreas/POLARCAT_FRANCE/.

Backward simulations as described in Stohl et al. (2003) were run to determine potential pathways and source contributions of the observed pollution plumes. 60000 virtual particles were released at each time step when the aircraft position changed more than $0.30^{\circ}$ horizontally or $150 \mathrm{~m}$ vertically. The virtual particles carrying tracers with passive and aerosol-like characteristics were followed for 20 days backward in time with the aerosol-like tracer species additionally being subject to dry and wet deposition. This allows for determination of emission sensitivities and source contributions, both calculated at $0.5^{\circ}$ horizontal resolution, based on available emission fluxes (Stohl et al., 2003). The emission sensitivity does not consider any specific emission source or a specific tracer. Only later, as part of the post-processing, the emission sensitivity is folded with specific emission fields such as for sulphur, BC or CO. Thus, the difference between the various aerosol-like tracers is based solely on the emission source distribution.

For anthropogenic emissions, the EDGAR emissions inventory version 3.2FT for the year 2000 (Olivier and Berdowski, 2001) was used outside of North America and Europe, while the inventory of Frost et al. (2006) for North America and the EMEP inventory for 2005 for Europe were applied. For black carbon emissions, the inventory of Bond et al. (2004) was used. Emissions from BB were modelled as described by Stohl et al. (2007) using fire locations detected by the moderate-resolution imaging spectrometer (MODIS) on the Aqua and Terra satellites and a land-cover vegetation classification. Smoke was injected within the lowest $100 \mathrm{~m}$ above the surface; it quickly mixed vertically to fill the planetary boundary layer.
Domain-filling forward simulations were used for the determination of the vertical extent of the polluted air masses. Passive CO tracers and aerosol-like BC tracers were released at the surface, using the same emission information as for the backward simulations. For both, forward and backward calculations, the concentrations of these two tracers bracket the loading of actual aerosol particles. The passive tracer does not suffer any wash-out at all, while for aerosol-like tracers in-cloud and below-cloud scavenging is applied assuming scavenging properties similar to sulphate. These properties are also applied immediately after emission when real $\mathrm{BC}$ still would have hydrophobic properties. Therefore, wet deposition is generally overestimated. The passive tracer concentration indicates a possible maximum aerosol loading while the hygroscopic aerosol-like tracer represents the lower limit. The ratio of aerosol-like and passive tracer indicates the potential wash-out of aerosol particles. Additionally, a $\mathrm{CO}$ passive fire tracer was calculated for the purpose of distinguishing between $\mathrm{CO}$ contributions from biomass burning and anthropogenic activities.

\subsection{Trajectory models}

Two trajectory models, the OFFLINE trajectory model (Methven, 1997; Methven et al., 2003) and the Lagrangian Analysis Tool, LAGRANTO, (Wernli and Davies, 1997), were used for detailed plume analysis. Input data was retrieved from ECMWF operational analyses and interpolated to Lagrangian particle position to calculate meteorological parameters, such as temperature, pressure, relative humidity, cloud cover, and potential vorticity along 10-day backward trajectories. Both models initialised the back trajectories every one minute and advected them backwards with a 30-min time step. Trajectory start point was the aircraft position itself for the OFFLINE model, and a box of $1 \mathrm{~km}$ diameter and $200 \mathrm{~m}$ height centred at the aircraft position from where 100 trajectories were randomly released for LAGRANTO.

\section{Characterisation of individual pollution plumes}

The campaign was divided into two phases according to the prevailing meteorological conditions, and hence source regions of air masses. Phase 1 (30 June to 10 July) was characterised by air mass transport from North America with advection of BB plumes from fires in Saskatchewan, Canada, and FF pollution from the Great Lakes area, Ohio Valley (steel industry), and the East Coast, USA. During phase 2 from 12 to 14 July, air masses were advected across the North Pole (Sodemann et al., 2010), carrying pollution from BB in Siberia and FF in East Asia. Some contributions of FF from Europe were also detected within the second period. During 8 scientific flights 48 pollution episodes (denoted as "plumes", see Table 3) were identified using the criteria stated below. 
Table 3. List of all 48 identified pollution plumes. The highlighted plumes were used for the aerosol lifetime calculation (see Fig. 14).

\begin{tabular}{|c|c|c|c|c|}
\hline Date & Time & Class & Sub-class & mean aerosol concentration \\
\hline 2008 & UTC & & & $\left(\mu \mathrm{g} \mathrm{m}^{-3}\right)$ \\
\hline \multirow[t]{3}{*}{30 June } & $14: 14-14: 24$ & $\mathrm{BB} / \mathrm{FF}$ no Asia & EU FF, Can BB & $1.61 \pm 0.83$ \\
\hline & $15: 08-15: 12$ & BB/FF no Asia & NA, EU FF, Can BB & $1.61 \pm 1.00$ \\
\hline & $16: 12-16: 18$ & $\mathrm{BB} / \mathrm{FF}$ no Asia & NA, EU FF, Can BB & $1.62 \pm 1.22$ \\
\hline \multirow[t]{10}{*}{8 July } & $13: 14-13: 32$ & “pure” BB (Plume I) & Can BB, Sib BB & $0.82 \pm 0.35$ \\
\hline & $13: 34-13: 38$ & "pure" BB & Can BB, Sib BB & $0.47 \pm 0.32$ \\
\hline & $13: 46-13: 56$ & "pure" BB & Can BB, Sib BB & $0.63 \pm 0.42$ \\
\hline & $13: 56-14: 02$ & BB/FF no Asia & $\mathrm{NA} \mathrm{BB} / \mathrm{FF}$ & $0.51 \pm 0.20$ \\
\hline & $14: 18-14: 24$ & BB/FF no Asia & $\mathrm{NA} \mathrm{BB} / \mathrm{FF}$ & $0.53 \pm 0.27$ \\
\hline & $14: 42-14: 52$ & $\mathrm{BB} / \mathrm{FF}$ no Asia & $\mathrm{NA} \mathrm{BB/FF}$ & $0.42 \pm 0.20$ \\
\hline & 14:52-15:02 & NA/EU, FF/little BB (Plume II) & NA FF/little BB & $0.62 \pm 0.35$ \\
\hline & 15:02-15:08 & NA/EU, FF/little BB (outlier) & NA FF/little BB & $\mathbf{0 . 3 5} \pm \mathbf{0 . 1 8}$ \\
\hline & $15: 24-15: 32$ & $\mathrm{BB} / \mathrm{FF}$ no Asia & $\mathrm{NA} \mathrm{BB} / \mathrm{FF}$ & $0.40 \pm 0.48$ \\
\hline & $15: 40-15: 50$ & NA/EU, FF/little BB (Plume III) & NA FF/little BB & $0.63 \pm 0.32$ \\
\hline \multirow[t]{5}{*}{10 July } & $14: 48-14: 58$ & BB/FF no Asia & $\mathrm{NA} \mathrm{BB} / \mathrm{FF}$ & $0.48 \pm 0.36$ \\
\hline & $15: 10-15: 18$ & "pure" BB & Can BB, Sib BB & $0.42 \pm 0.21$ \\
\hline & $15: 22-15: 28$ & NA/EU, FF/little BB & NA FF/little BB & $0.37 \pm 0.31$ \\
\hline & $15: 42-15: 52$ & NA/EU, FF/little BB & NA FF/little BB & $0.39 \pm 0.32$ \\
\hline & $15: 52-16: 02$ & BB/FF no Asia & NA BB/FF & $0.36 \pm 0.30$ \\
\hline \multirow[t]{9}{*}{12 July a } & $11: 30-11: 36$ & NA/EU, FF/little BB & NA FF/little BB & $\mathbf{0 . 5 7} \pm \mathbf{0 . 2 8}$ \\
\hline & 11:40-12:00 & NA/EU, FF/little BB & NA FF/little BB & $0.52 \pm 0.26$ \\
\hline & $12: 24-12: 28$ & BB/FF no Asia & NA FF/BB & $0.58 \pm 0.28$ \\
\hline & $12: 28-12: 34$ & NA/EU, FF/little BB & NA FF/little BB & $0.45 \pm 0.21$ \\
\hline & $12: 44-12: 52$ & BB/FF no Asia & NA FF/BB & $0.34 \pm 0.16$ \\
\hline & $12: 58-13: 06$ & $\mathrm{BB} / \mathrm{FF}$ no Asia & NA FF/BB & $0.61 \pm 0.36$ \\
\hline & $13: 12-13: 18$ & NA/EU, FF/little BB & NA FF/little BB & $\mathbf{0 . 3 7} \pm \mathbf{0 . 3 7}$ \\
\hline & $13: 30-13: 36$ & NA/EU, FF/little BB & NA FF/little BB & $0.32 \pm 0.20$ \\
\hline & $13: 44-13: 54$ & BB/FF no Asia & EU FF, Can BB & $0.42 \pm 0.20$ \\
\hline \multirow[t]{4}{*}{12 July b } & $18: 28-18: 46$ & BB/FF no Asia & $\mathrm{NA} \mathrm{BB} / \mathrm{FF}$ & $0.56 \pm 0.41$ \\
\hline & 19:06-19:16 & BB/FF no Asia & $\mathrm{NA} \mathrm{BB} / \mathrm{FF}$ & $0.69 \pm 0.30$ \\
\hline & $19: 24-19: 42$ & BB/FF no Asia & NA FF/BB & $0.55 \pm 0.28$ \\
\hline & 19:48-20:02 & BB/FF no Asia & NA BB/FF & $0.52 \pm 0.28$ \\
\hline \multirow[t]{9}{*}{13 July } & $18: 24-18: 30$ & $\mathrm{BB} / \mathrm{FF}$ no Asia (Plume $\mathrm{V}_{\text {ref }}$ ) & $\mathrm{NA} \mathrm{BB} / \mathrm{FF}$ & $1.24 \pm 0.40$ \\
\hline & $18: 34-18: 40$ & $\mathrm{BB} / \mathrm{FF}$ no Asia & NA BB/FF & $0.96 \pm 0.42$ \\
\hline & $18: 42-19: 06$ & Asia FF/Sib BB (Plume IV) & Asia FF/Sib BB & $0.98 \pm 0.40$ \\
\hline & $19: 18-19: 24$ & NA/EU, FF/little BB & EU FF, NA FF & $1.25 \pm 0.60$ \\
\hline & $19: 28-19: 36$ & NA/EU, FF/little BB & EU FF, NA FF & $0.92 \pm 0.34$ \\
\hline & $19: 36-19: 40$ & Sib BB/Asia FF & Sib BB/Asia FF & $0.40 \pm 0.26$ \\
\hline & 19:56-20:02 & Sib BB/Asia FF (Plume V) & Sib BB/Asia FF & $0.26 \pm 0.26$ \\
\hline & $20: 10-20: 16$ & $\mathrm{Sib} \mathrm{BB} / \mathrm{Asia} \mathrm{FF}$ & Sib BB/Asia FF & $0.84 \pm 0.43$ \\
\hline & $20: 16-20: 20$ & BB/FF no Asia & $\mathrm{NA} \mathrm{BB} / \mathrm{FF}$ & $0.69 \pm 0.45$ \\
\hline 14 July a & $12: 18-12: 26$ & Sib BB/Asia FF & Sib BB/Asia FF & $0.75 \pm 0.33$ \\
\hline \multirow[t]{7}{*}{14 July b } & $14: 30-14: 42$ & BB/FF no Asia & EU FF, Can BB & $1.39 \pm 0.57$ \\
\hline & $15: 50-15: 56$ & Asia FF/Sib BB & Asia FF/Sib BB & $0.95 \pm 0.60$ \\
\hline & $15: 58-16: 04$ & Asia FF/Sib BB & Asia FF/Sib BB & $1.03 \pm 0.65$ \\
\hline & 16:04-16:08 & Asia FF/Sib BB & Asia FF/Sib BB & $1.32 \pm 0.54$ \\
\hline & $16: 08-16: 16$ & Asia FF/Sib BB & Asia FF/Sib BB & $1.24 \pm 0.50$ \\
\hline & $16: 22-16: 28$ & BB/FF no Asia & NA BB/FF & $0.86 \pm 0.63$ \\
\hline & $16: 30-16: 40$ & BB/FF no Asia & $\mathrm{NA} \mathrm{BB} / \mathrm{FF}$ & $0.80 \pm 0.43$ \\
\hline
\end{tabular}

BB, biomass burning; FF, fossil fuel combustion; NA, North America; EU, Europe; Sib, Siberia; Asia, East Asia; class and sub-class names are composed according to the importance of the pollution contribution. 
The identification of pollution plumes within the aircraft data time series was conducted manually by taking into consideration the following parameters:

1. Increased concentrations of at least $0.1 \mu \mathrm{g} \mathrm{m}^{-3}$ (STP) of particulate sulphate and/or organic aerosol relative to the immediate surroundings,

2. a particle signature of at least $0.01 \mu \mathrm{m}^{3} \mathrm{~cm}^{-3}$ (STP) in the volume size distribution $(d V / d \log (d p))$ of accumulation mode particles measured by the SMPS,

3. an increase of at least $10 \mathrm{nmol} \mathrm{mol}^{-1} \mathrm{CO}$ and/or $\mathrm{O}_{3}$ mixing ratio relative to the immediate surroundings, and

4. an identifiable source-receptor relationship modelled by FLEXPART.

For an episode to be recognized as plume either (1) and (2) and (4); or (3) and (4) had to be fulfilled. The shortest identified pollution episodes involve three AMS data points of 2 min time resolution. Since the AMS limit of detection was elevated during most of the flights 9 plumes were below the 3 sigma LOD but above the 1 sigma LOD and 8 plumes were below the 1 sigma LOD. In some of these pollution plumes only gaseous tracers were enhanced, while during others either particulate sulphate or organics were elevated and the other below LOD due to the nature of the emission source. These events were still accounted for because the SMPS data clearly showed the presence of enhanced particle number densities and AMS mass concentrations were locally elevated. For POLARCAT-France measurements, SMPS volume size distribution data can be compared qualitatively to AMS mass concentration data within certain constraints. The particle size ranges of the SMPS, $20-500 \mathrm{~nm}$ mobility diameter $\left(d_{\mathrm{mob}}\right)$, and the AMS, $80-1000 \mathrm{~nm}$ vacuum aerodynamic diameter $\left(d_{\mathrm{va}}\right)$, are comparable. Although the shape factor and density of the measured aerosol are not known, it is expected that whenever the SMPS detects a clear signal in accumulation mode particles the AMS will detect a mass signal. Even though the SMPS signal includes refractory aerosol components, such as mineral dust and $\mathrm{BC}$, it is very likely that when $\mathrm{BC}$ aerosol is present it is either coated or accompanied by non-refractory compounds which the AMS can detect. $\mathrm{BC}$ emissions, which are expected to be advected to Greenland from FF and BB emissions, are always accompanied by release of VOCs (volatile organic compounds) in both cases and $\mathrm{SO}_{2}$ during fossil fuel combustion. These gas phase components will undergo chemical change over time and transport and partition to the particle phase (e.g. Hallquist et al., 2009).

\subsection{Case studies}

The following subsections intend to give a more detailed insight into the meteorological conditions during the POLARCAT campaign and to highlight the strong variability in the observed pollution events resulting from this situation. The following aspects are discussed by means of 6 selected pollution episodes (Tables 3 and 4) observed on 8 and 13 July, 2008: source regions and types, gas and particle phase chemical characteristics, transport times, pathways, patterns and aerosol scavenging.

\subsubsection{Flight description and meteorological situation on 8 and 13 July 2008}

The flight on 8 July started in Kangerlussuaq, passed over the Greenland ice sheet heading south, flew over the Atlantic Ocean, and then returned to Narsarsuaq, Southern Greenland (dark blue trace, Fig. 1). Due to an intense low pressure system tracking from North America towards southern Greenland, mainly air masses from Canada and the United States were sampled (see Fig. 2). A strong warm conveyor belt (WCB) associated with this low pressure system lifted warm and humid air masses from North America up to $400 \mathrm{hPa}$ and advected them towards southern Greenland over approximately 3 days. According to FLEXPART, transport times from North America were between three and nine days. During the flight, the aircraft crossed several clouds, thus aerosol was sampled in and outside of clouds. Figure 3 a shows the time series of altitude, $\mathrm{CO}$ and $\mathrm{O}_{3}$ at $1 \mathrm{~s}$ time resolution. Insitu relative humidity equal to or greater than $100 \%$ is indicated by striped areas. Panel b presents AMS sulphate and organic aerosol measurements at two minutes time resolution. The SMPS volume size distribution at STP with $130 \mathrm{~s}$ time resolution in $\mu \mathrm{m}^{3} \mathrm{~cm}^{-3}$ is shown in Fig. 3e. Panel c compares the FLEXPART backwards simulated excess total $\mathrm{CO}$ (grey) and BB CO (brown) with the in-situ measured CO minus $100 \mathrm{nmol} \mathrm{mol}^{-1}$ (called measured excess CO). Panel $d$ provides an estimation of aerosol wash-out based on the ratio of $\mathrm{BC}$ aerosol-like and passive tracers. The unit-less percentage indicates the amount of aerosol which has not been scavenged. The very low numbers indicate that the majority of particulate matter has potentially been removed during transport towards Greenland.

On 13 July 2008, the ATR-42 flew from Kangerlussuaq straight over Baffin Bay in NW direction to a turning point at $70.1^{\circ} \mathrm{N}, 60.4^{\circ} \mathrm{W}$ from where it returned on the same path. The first leg was flown at $7.3 \mathrm{~km}$ altitude while during the return the altitude varied between 4.6 and $5.8 \mathrm{~km}$ a.s.l. (Fig. 1 and Fig. 4a) to cross forecasted pollution plumes at various altitudes. During this period, Asian pollution was transported across the pole associated with the development of a low pressure system over the East Siberian Sea (Sodemann et al., 2010). At the same time another low pressure system, originating from North America, travelled north along the eastern coast of Greenland. Pollution plumes sampled between these two low-pressure systems were in a region of stretching and filamentation leading to the formation of fine-scale features in the measurements (shown in detail by Sodemann et al., 2010). According to FLEXPART, this flight was influenced 
Table 4. Overview of campaign characteristic pollution plumes (discussed in detail in Sect. 4).

\begin{tabular}{|c|c|c|c|c|c|}
\hline & Plume I & Plume II & Plume III & Plume IV & Plume V \\
\hline coordinates & $\begin{array}{l}66.3-65.5^{\circ} \mathrm{N} \\
49.9-49.1^{\circ} \mathrm{W}\end{array}$ & $\begin{array}{l}61.1-60.5^{\circ} \mathrm{N} \\
45.4^{\circ} \mathrm{W}\end{array}$ & $\begin{array}{l}60.5-61.1^{\circ} \mathrm{N} \\
45.4^{\circ} \mathrm{W}\end{array}$ & $\begin{array}{l}68.4-69.4^{\circ} \mathrm{N} \\
54.8-57.8^{\circ} \mathrm{W}\end{array}$ & $\begin{array}{l}68.7-69.0^{\circ} \mathrm{N}, \\
55.6-56.4^{\circ} \mathrm{W}\end{array}$ \\
\hline altitude $(\mathrm{km})$ & $4.2-5.0$ & 7.6 & $2.1-3.0$ & 7.3 & 5.7 \\
\hline date/time (UTC) & $\begin{array}{l}8 \text { July } 2008, \\
13: 14-13: 32\end{array}$ & $\begin{array}{l}8 \text { July } 2008, \\
14: 52-15: 02\end{array}$ & $\begin{array}{l}8 \text { July } 2008, \\
15: 40-15: 50\end{array}$ & $\begin{array}{l}13 \text { July } 2008 \text {, } \\
18: 42-19: 06\end{array}$ & $\begin{array}{l}13 \text { July } 2008, \\
19: 56-20: 02\end{array}$ \\
\hline extension $(\mathrm{km})$ & 108 & 60 & 60 & 150 & 72 \\
\hline origin & BB, Canada & $\begin{array}{l}\text { BB, Canada } \\
\text { FF, Great Lakes }\end{array}$ & $\begin{array}{l}\text { FF, Ohio Valley, Great } \\
\text { Lakes BB, Canada }\end{array}$ & $\begin{array}{l}\text { FF, Asia } \\
\text { BB, Siberia }\end{array}$ & $\begin{array}{l}\text { BB, Siberia } \\
\text { FF, Asia }\end{array}$ \\
\hline age (days) & 7 & $\begin{array}{l}6-11 \\
3-4\end{array}$ & $\begin{array}{l}>7 \\
5-8\end{array}$ & $6-11$ & $6-11$ \\
\hline maximum AMS derived mass $\left(\mu \mathrm{g} \mathrm{m}^{-3}\right)$ & 1.11 & 0.96 & 0.73 & 1.30 & 0.22 \\
\hline fraction of particulate organics (\%) & $90 \pm 12$ & $82 \pm 4$ & $55 \pm 17$ & $52 \pm 22$ & - \\
\hline$\Delta \mathrm{CO}\left(\mathrm{nmol} \mathrm{mol}^{-1}\right)$ & 30 & 27 & - & -16 & 30 \\
\hline$\Delta \mathrm{O}_{3}\left(\mathrm{nmol} \mathrm{mol}^{-1}\right)$ & 10 & 45 & - & 50 & -24 \\
\hline
\end{tabular}

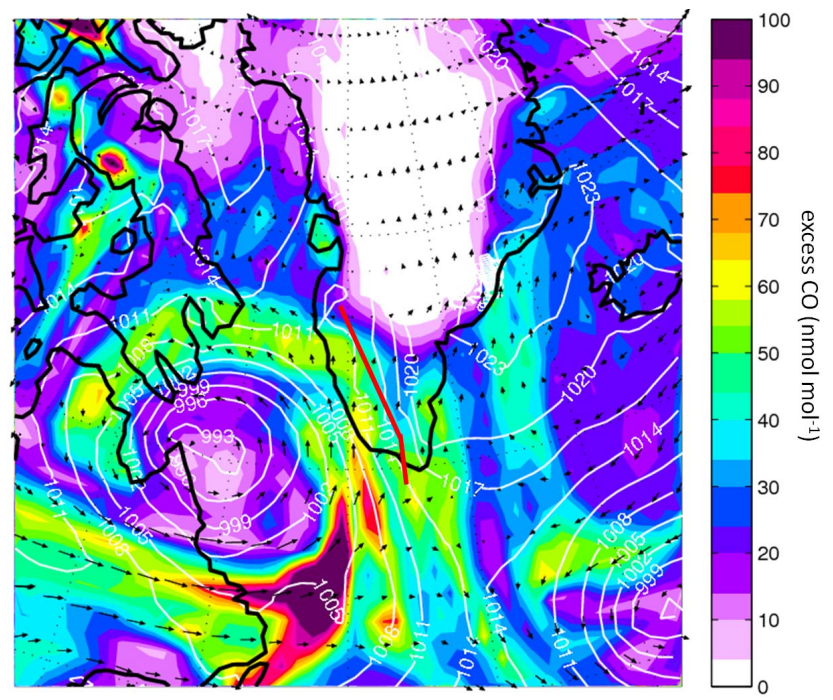

Fig. 2. Low pressure system west of Greenland on 8 July at 15:00 UTC at $5000 \mathrm{~m}$ altitude. The colour-code denotes FLEXPART derived excess $\mathrm{CO}$ mixing ratio in $\mathrm{nmol} \mathrm{mol}^{-1}$, the white contours represent surface pressure levels from 980 to $1030 \mathrm{hPa}$ in $3 \mathrm{hPa}$ intervals. The red trace indicates the flight track on 8 July 2008.

by a variety of air masses from different origins leading to high variability in air mass transport times which ranged between 10 and 17 days for Asia and around one week for NA and Europe. Figure 4 provides the same information as Fig. 3 for this specific flight.

The plumes which are discussed in the following analysis are represented by roman numbers in chronological order in Figs. 3 and 4. An overview of plume origin, coordinates, and main characteristics is given in Table 4.

\subsubsection{Aerosol and trace gas enhancement from Canadian BB}

Plume I sampled on 8 July (Figs. 3 and 5a) is an example for advection of nearly pure BB pollution out of Canada through the free troposphere towards Greenland. After one week of transport, clear enhancements of submicron aerosol concentration, ozone, and $\mathrm{CO}$ were observed over the inland ice in Greenland. The chemical composition of the aerosol is characterised by a mass fraction of $90 \pm 12 \%$ organics, an average total mass of $0.82 \pm 0.35 \mathrm{\mu g} \mathrm{m}^{-3}$, while $\Delta \mathrm{CO}$ is $30 \mathrm{nmol} \mathrm{mol}^{-1}$, and $\Delta \mathrm{O}_{3}$ is $10 \mathrm{nmol} \mathrm{mol}^{-1}$ for the period during which the aircraft moved at a constant altitude. The trace gas delta values are calculated by subtracting the average mixing ratio before and after the plume from the peak value during the pollution episode. Between 13:24 and 13:26 UTC all aerosol and trace gas signals drop simultaneously. Potentially, the aircraft shortly moved out of the plume. The $\mathrm{CO}$ detector shows no signal during these two minutes due to internal calibrations. Even though according to Fig. $3 \mathrm{~b}$ and $\mathrm{c}$ the ATR-42 flew only through a faint $\mathrm{CO}$ and mostly washed-out BC signature, it is obvious from FLEXPART column-integrated emission sensitivity in Fig. 5a that this air mass was influenced by BB in Canada (the red and black dots indicate MODIS fire counts for forest and other land use, respectively). According to back trajectory calculations by the OFFLINE model, most of the air masses picked up BB signatures at $600 \mathrm{hPa}$ and were lifted to about $400 \mathrm{hPa}$ close to the east coast of North America and then travelled between 600 and $500 \mathrm{hPa}$ before interception. 


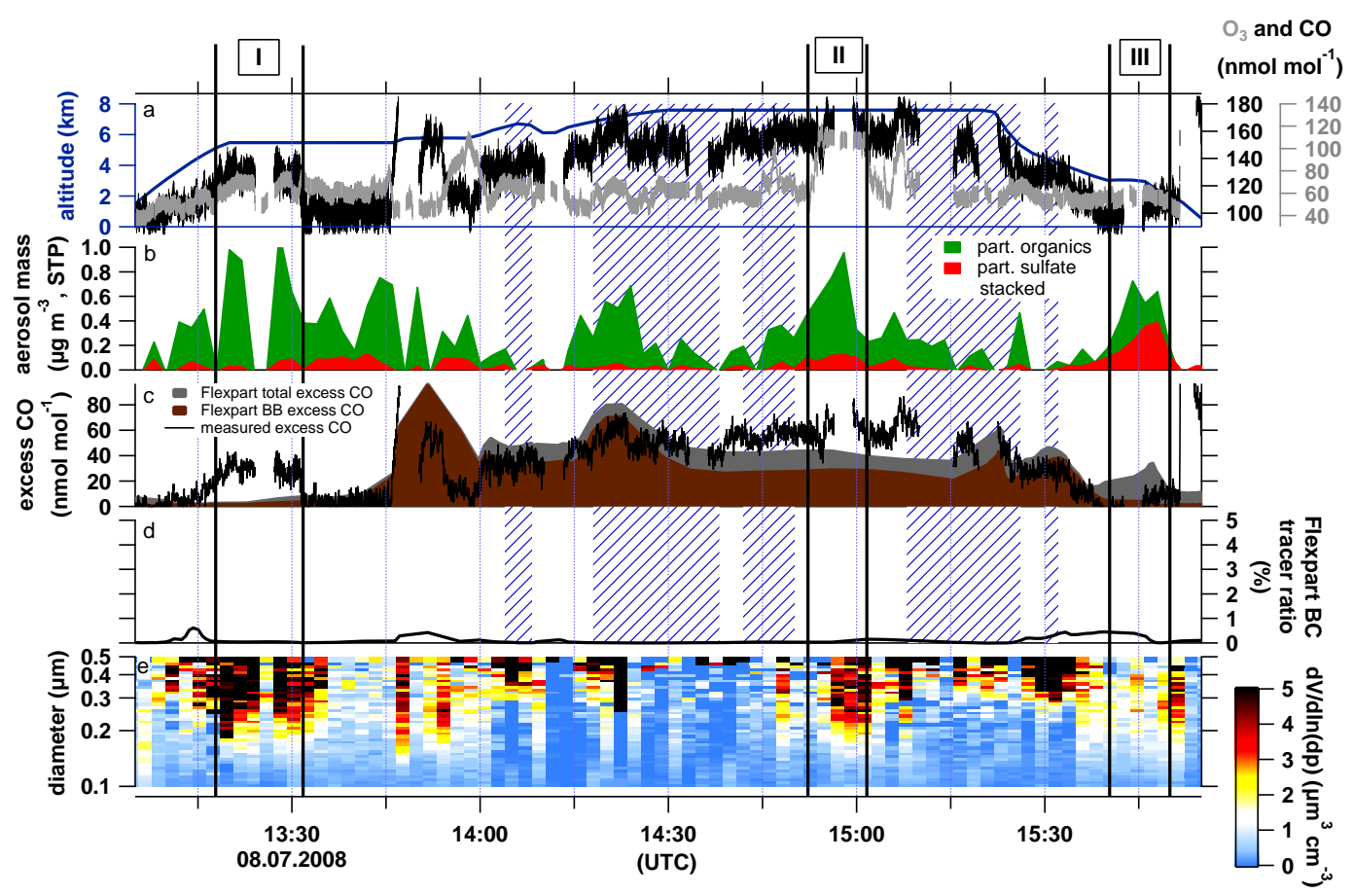

Fig. 3. 8 July, 2008. (a) Aircraft altitude (blue) and trace gas mixing ratios (grey $\mathrm{O}_{3}$, black $\mathrm{CO}$ ) in one second time resolution, the blue striped areas denote relative humidity equal to or greater than $100 \%$. (b) AMS sulphate and organic aerosol mass concentration (stacked) in two minutes time resolution. (c) FLEXPART excess total and biomass burning (BB) CO and measured excess CO (actual concentration minus $100 \mathrm{nmol} \mathrm{mol}^{-1}$ ), (d) ratio of FLEXPART BC aerosol-like and passive tracer, (e) SMPS volume size distribution at STP. The areas between the black bars with roman numbers indicate the discussed plumes.

\subsubsection{Aerosol enhancement from North American BB and $\mathrm{FF}$ pollution with minimal trace gas signature}

While in Sect. 4.1.2 both trace gases and particle signatures were elevated, another case from 8 July (Plume III, Figs. 3 and $5 \mathrm{c}$, d) illustrates a situation where BB pollution from Canada mixed with FF outflow from the Ohio Valley was sampled but only aerosol concentrations are markedly elevated. Plume III was sampled between 3.0 and $2.1 \mathrm{~km}$ altitude during the descent to Narsarsuaq while traversing a layer of low level clouds. Both aerosol instruments (Fig. 3b and e) indicate a clearly defined particle plume. Organic matter increases steeply from below detection limit to $0.49 \mu \mathrm{g} \mathrm{m}^{-3}$ until 15:44 UTC, while particulate sulphate peaks around 15:48 UTC with $0.39 \mu \mathrm{g} \mathrm{m}^{-3}$. The occurrence of one peak after another suggests that two distinct sources are intermingled in the 10 min measurement interval occurring over $60 \mathrm{~km}$. The ozone mixing ratio remains constant throughout the encounter, while the $\mathrm{CO}$ mixing ratio increases slightly from roughly 100 to $110 \mathrm{nmol} \mathrm{mol}^{-1}$ including a period of instrument calibration. It is difficult to determine whether the increase in $\mathrm{CO}$ is due to the plume or due to local emissions from Narsarsuaq. The FLEXPART column-integrated emission sensitivity (Fig. 5c) suggests that the first part of this plume encounter was influenced by Canadian BB. The source region and transport of this episode are comparable to Plume I. However, while in both cases organic aerosol is markedly enhanced, $\mathrm{CO}$ is not in the second case. This result clearly shows that considering both gas and aerosol phase is important to fully identify pollution events. During the second part of the plume encounter the source region shifts south to the Great Lakes area, the Ohio Valley and the US East Coast (Fig. 5d). Parts of these areas are densely populated and heavily industrialized which may explain the high contribution of sulphate aerosol to this plume. The ratio of FLEXPART $\mathrm{SO}_{2}$ and $\mathrm{CO}$ passive tracers is significantly higher during this episode than during the rest of the flight (not shown). Such enhanced $\mathrm{SO}_{2}$ emissions indicate pollution contributions from New York and the Ohio Valley area based on the EDGAR 32FT2000 emission inventory. The FLEXPART CO fire tracer contributes less than 5\% during this episode to the total $\mathrm{CO}$. The relative humidity at the start point of this plume is $31 \%$ while it increases steadily and peaks at $86 \%$ together with the particulate sulphate concentration. It is conceivable that the distinct particulate sulphate signature is a result of $\mathrm{SO}_{2}$ processing in clouds further above. Transport times were longer than one week for the BB contributions, and between 5-8 days for FF (see Fig. 5c, d). Based on the OFFLINE model, the BB air mass trajectories were uplifted from approximately $800 \mathrm{hPa}$ to $550 \mathrm{hPa}$ after 


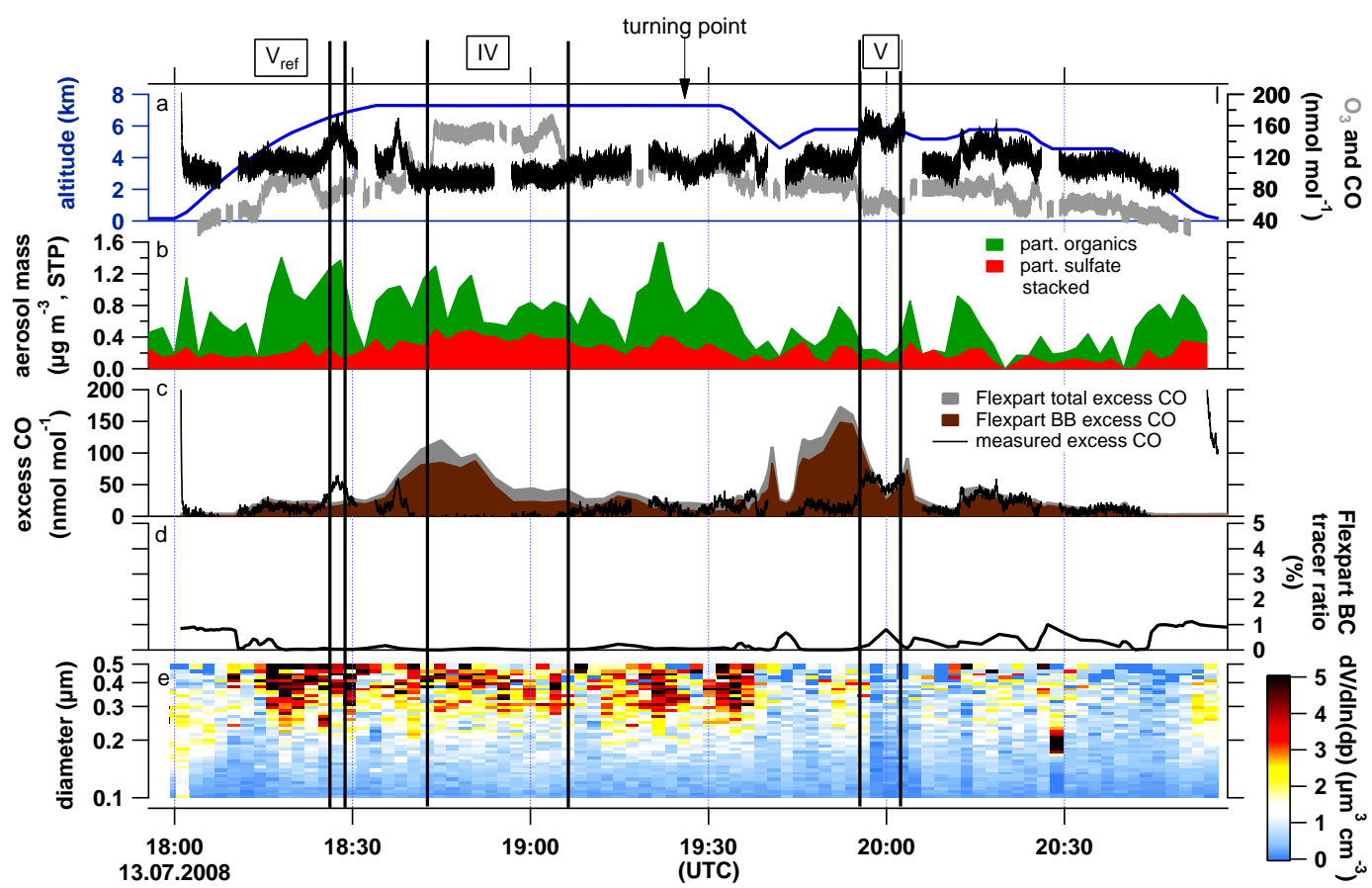

Fig. 4. 13 July 2008. (a) Aircraft altitude (blue) and trace gas mixing ratios (grey $\mathrm{O}_{3}$, black $\mathrm{CO}$ ) in one second time resolution, the blue striped areas denote relative humidity equal to or greater than $100 \%$. (b) AMS sulphate and organic aerosol mass concentration (stacked) in two minutes time resolution. (c) FLEXPART excess total and biomass burning (BB) $\mathrm{CO}$ and measured excess $\mathrm{CO}$ (actual concentration minus $100 \mathrm{nmol} \mathrm{mol}^{-1}$ ), (d) ratio of FLEXPART BC aerosol-like and passive tracer, (e) SMPS volume size distribution at STP. The areas between the black bars with roman numbers indicate the discussed plumes.
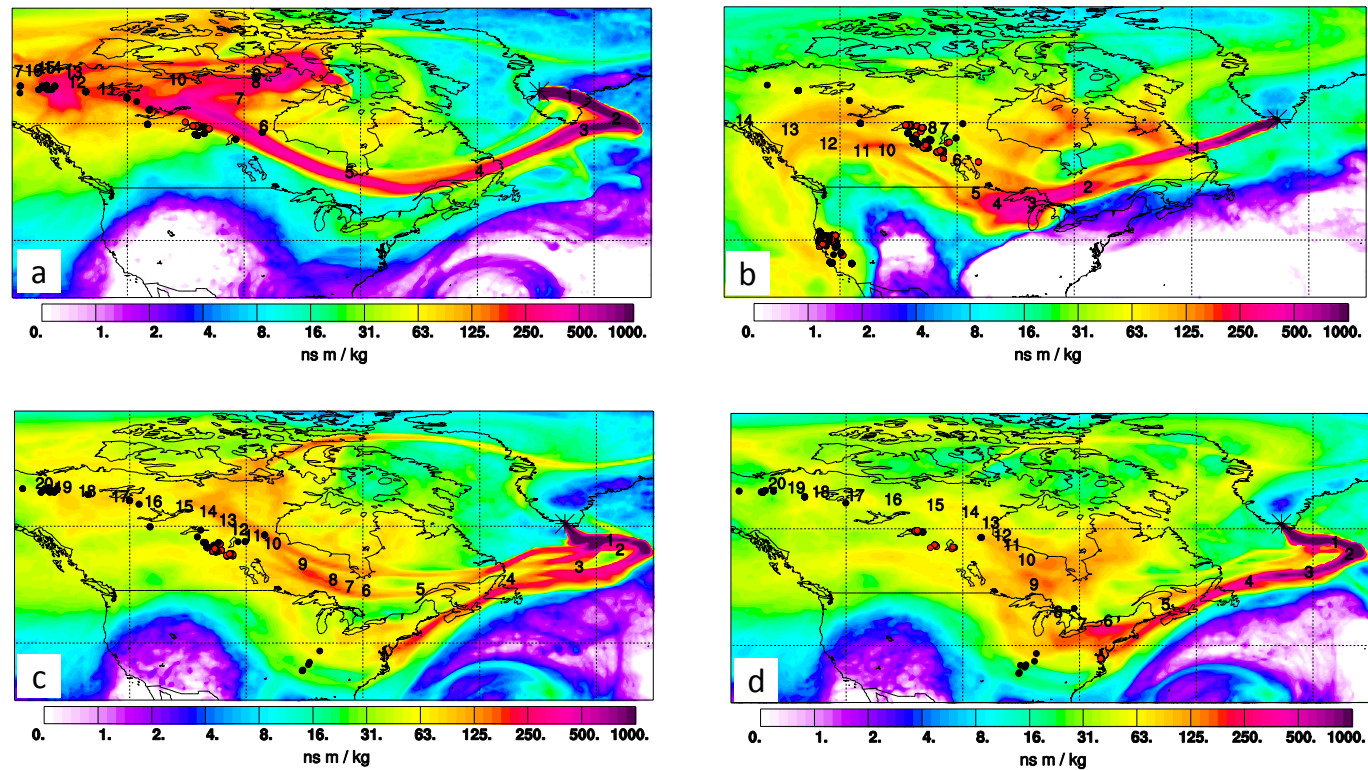

Fig. 5. Column-integrated emission sensitivity on 8 July 2008 for Plume I to III. (a) Plume I, 13:27:45-13:31:47 UTC, shows BB contributions from Canada. (b) Plume II, 14:56:03-15:01:40 UTC, shows FF influence from the Great Lakes area and BB contributions from Canada and the US West Coast. (c) Plume III, 15:39:35-15:44:16 UTC, presents BB influence from Canada and FF contribution from the Ohio Valley and US East Coast. (d) Plume III, 15:46:08-15:46:43 UTC, shows contributions of FF from the Ohio Valley, Great Lakes area and the US East Coast and some BB influence from Canada. 

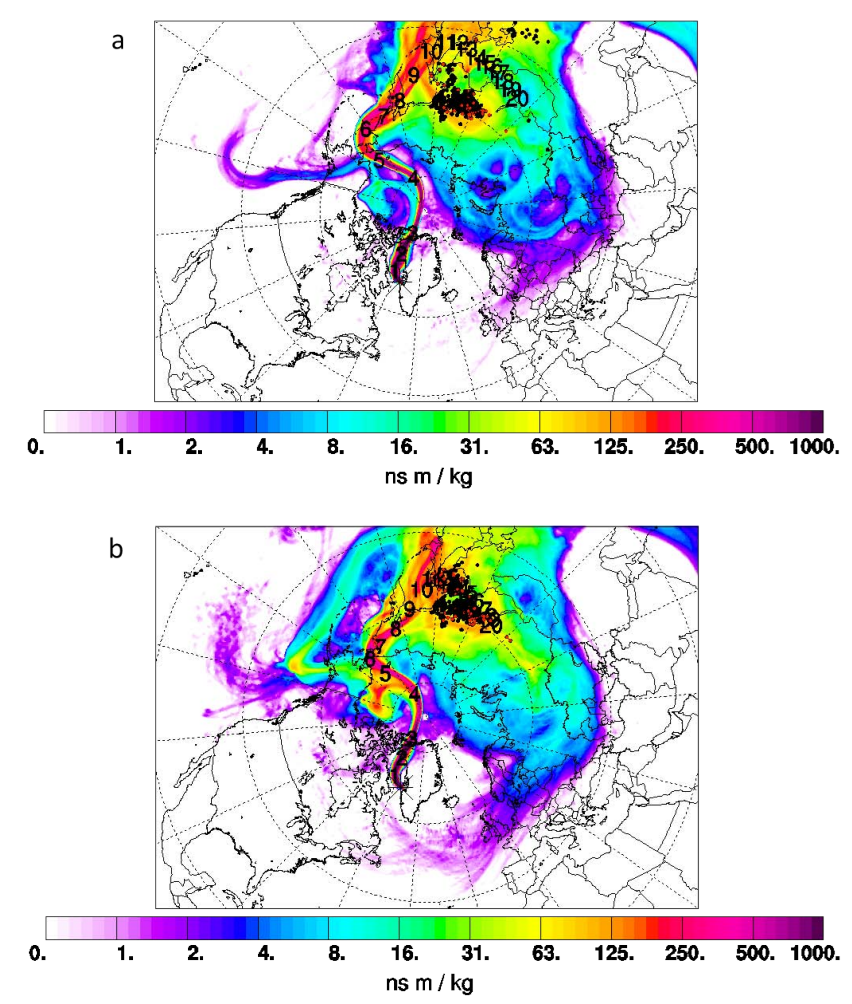

Fig. 6. FLEXPART column-integrated emission sensitivity on 13 July 2008 for (a) Plume IV, 18:41:32-18:44:54 UTC, and (b) Plume V, 20:02:51-20:03:31 UTC, both showing influences from mixed Asian FF and Siberian BB pollution.

passing over the fires and then descended slowly within 42 hours to $700 \mathrm{hPa}$ before detection over Greenland. The FF trajectories picked up pollution between 1000 and $850 \mathrm{hPa}$ before transport at low level towards Greenland where they were measured between 840 and $710 \mathrm{hPa}$.

\subsubsection{Strong CO enhancement and aerosol wash-out in WCB}

In contrast to the case discussed in Sect. 4.1.3, Plume V intercepted on 13 July (Fig. 4) exhibits a strong increase in the $\mathrm{CO}$ mixing ratio while ozone concentrations drop and the aerosol signature almost disappears. The $\mathrm{CO}$ mixing ratio is enhanced with $154 \mathrm{nmol} \mathrm{mol}^{-1}$ on average with a $\Delta \mathrm{CO}$ of $30 \mathrm{nmol} \mathrm{mol}^{-1}$, while the $\mathrm{O}_{3}$ mixing ratio drops to $61 \mathrm{nmol} \mathrm{mol}^{-1}$, still slightly elevated, corresponding to a $\Delta \mathrm{O}_{3}$ of $-24 \mathrm{nmol} \mathrm{mol}^{-1}$. Both aerosol instruments detect little signal. AMS aerosol total mass is $0.26 \pm 0.26 \mu \mathrm{g} \mathrm{m}^{-3}$. However, the air mass is influenced by Siberian BB and East Asian FF (Beijing region, Korea and Japan) based on the FLEXPART column-integrated emission sensitivity given in Fig. 6b. Considering the vertical extension of the plume by means of the FLEXPART CO passive tracer as shown in Fig. 7 the pollution episode was crossed at its highest con-

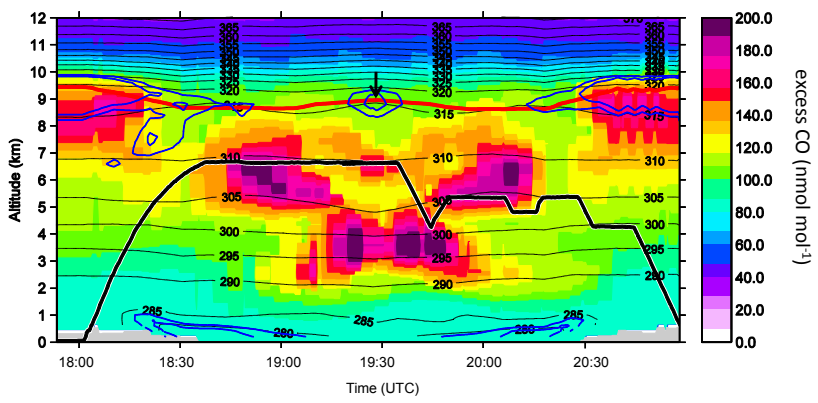

Fig. 7. FLEXPART calculations of excess CO passive tracer concentration in nmol mol${ }^{-1}$ along the flight track (thick black line). The thin black lines indicate potential temperature in $\mathrm{K}$, the thick red line denotes the 2 PVU isosurface, the thin blue contours show 80 and $90 \%$ relative humidity. The arrow indicates the turning point.

centration. This and the combination of elevated $\mathrm{CO}$ mixing ratio and very low signal intensity for aerosol detection suggests that this plume may have been influenced by aerosol wash-out. Thus, the gas phase pollution tracer $\mathrm{CO}$ survived transport from East Asia and Siberia while particles were deposited en-route. Roiger et al. (2011) describe the corresponding meteorological situation in detail including the rapid uplift of polluted air masses in a WCB by means of cloud top temperatures over East Asia and the subsequent cross-polar transport towards Greenland. Figure $8 \mathrm{a}$ and $\mathrm{b}$ display the median values of the meteorological field data along the trajectories calculated with LAGRANTO which are released within the given time frames (see below). In Fig. 8a (19:58:20-20:02:00 UTC) it is clearly visible from the cloud cover and precipitation that aerosol wash-out could have occurred around 110 to $70 \mathrm{~h}$ prior to interception during air mass uplift which can be associated to the WCB event. To contrast this period of high $\mathrm{CO}$ and low particulate matter abundance, Fig. 8b shows the vertical cross-section along the trajectory for the period 18:26:40-18:28:24 UTC of the same flight with a high $\mathrm{CO}$ mixing ratio of $151 \mathrm{nmol} \mathrm{mol}^{-1}$ and high total AMS aerosol mass of $1.24 \pm 0.40 \mu \mathrm{g} \mathrm{m}^{-3}$ (see label "V ref" in Fig. 4). Even though this plume corresponds primarily to Canadian BB and US anthropogenic emissions we compare it to Plume V in terms of total submicron aerosol mass loading because in both cases the $\mathrm{CO}$ mixing ratios are greater than $150 \mathrm{nmol} \mathrm{mol}^{-1}$. Therefore elevated particulate mass concentrations are expected for both events. While Plume V aerosol was very likely scavenged by a precipitation rate near $1 \mathrm{~mm} \mathrm{~h}^{-1}$ (see lower panel in Fig. 8a) during air mass ascent, Plume $\mathrm{V}_{\text {ref }}$ particles experienced much less precipitation en-route (maximum of $0.2 \mathrm{~mm} \mathrm{~h}^{-1}$, see Fig. $8 \mathrm{~b}$ lower panel). Therefore the measured aerosol mass concentration at $150 \mathrm{nmol} \mathrm{mol}^{-1} \mathrm{CO}$ mixing ratio is rather high within the context of this campaign. This analysis shows that relating enhanced $\mathrm{CO}$ mixing ratios to aerosol concentrations 


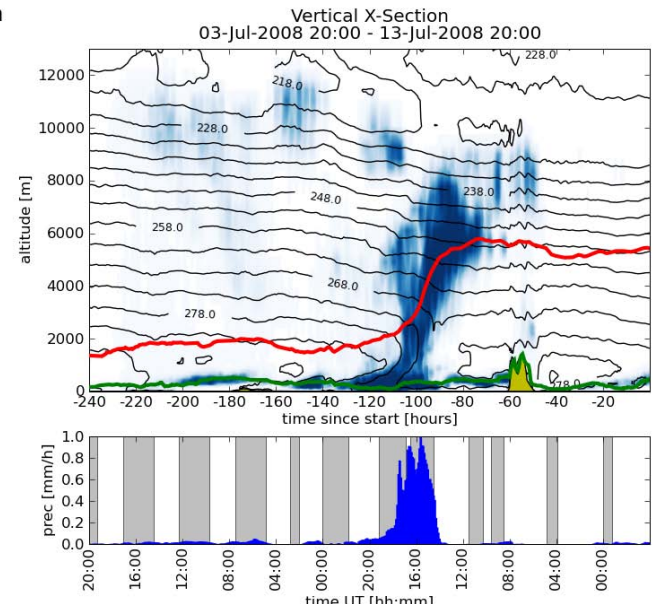

b

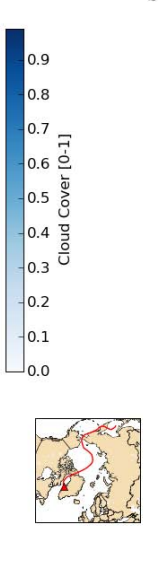

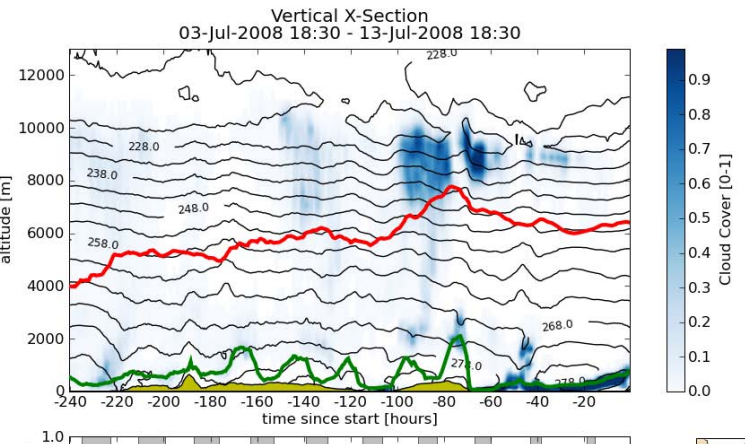

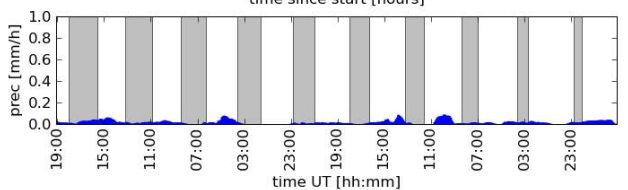

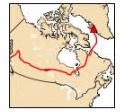

Fig. 8. Median values of the meteorological field data along the trajectories, released between 19:58:20-20:02:00 (a) and 18:26:40-18:28:24 (b). Blue shades indicate cloud cover, black contour lines temperature, the green line the boundary layer height, the yellow pattern the orography as given by the ECMWF data, and the red line the median position of the trajectory ensemble. The lower panel shows median precipitation values at the surface (blue columns) and night times along the trajectory pathway (grey shade).

becomes difficult as particulate matter is subject to aqueous removal processes while $\mathrm{CO}$ with a lifetime of roughly 12 months is more likely to be preserved (see more detailed discussion in Sect. 5.2).

\subsubsection{Significant aerosol and trace gas enhancement despite transport associated to WCB}

Unlike Plume V, Plume II sampled on 8 July (Figs. 3 and $5 b)$ provides an example in which pollution outflow is uplifted through a WCB and both trace gases and aerosol concentrations remain markedly enhanced over Greenland. $\Delta \mathrm{O}_{3}$ is approximately $45 \mathrm{nmol} \mathrm{mol}^{-1}$, and $\Delta \mathrm{CO}$ at least $27 \mathrm{nmol} \mathrm{mol}^{-1}$ (see Fig. 3). The $\Delta \mathrm{CO}$ is a lower estimate since internal instrument calibration took place during this period and the highest recorded $\mathrm{CO}$ value throughout the plume was used as peak value for the calculation. Outside this defined plume period $\triangle \mathrm{CO}$ is some $60 \mathrm{nmol} \mathrm{mol}^{-1}$ assuming $100 \mathrm{nmol} \mathrm{mol}^{-1}$ as background value (Fig. 3c). This implies that the event discussed here was embedded in an extensive polluted area. Both aerosol instruments show clear enhancements during the plume encounter compared to the surroundings. The AMS submicron aerosol mass has a mean of $0.62 \pm 0.35 \mu \mathrm{g} \mathrm{m}^{-3}$, peaks at $0.96 \mu \mathrm{g} \mathrm{m} \mathrm{m}^{-3}$, and is composed of $82 \pm 14 \%$ organic carbon. Figure $5 b$ shows that this plume is composed of a mixture of anthropogenic emissions from the Great Lakes area and forest fire emissions in Canada and possibly also at the US west coast. Transport times vary significantly depending on the source region: 3-4 days from the Great Lakes, 6-11 days from Canada, and greater than 12 days from the west coast. According to the OFFLINE model all trajectories raised from $900 \mathrm{hPa}$ between 72 and $60 \mathrm{~h}$ prior to plume detection at $380 \mathrm{hPa}$ (see Fig. 9 lower panel). Thus

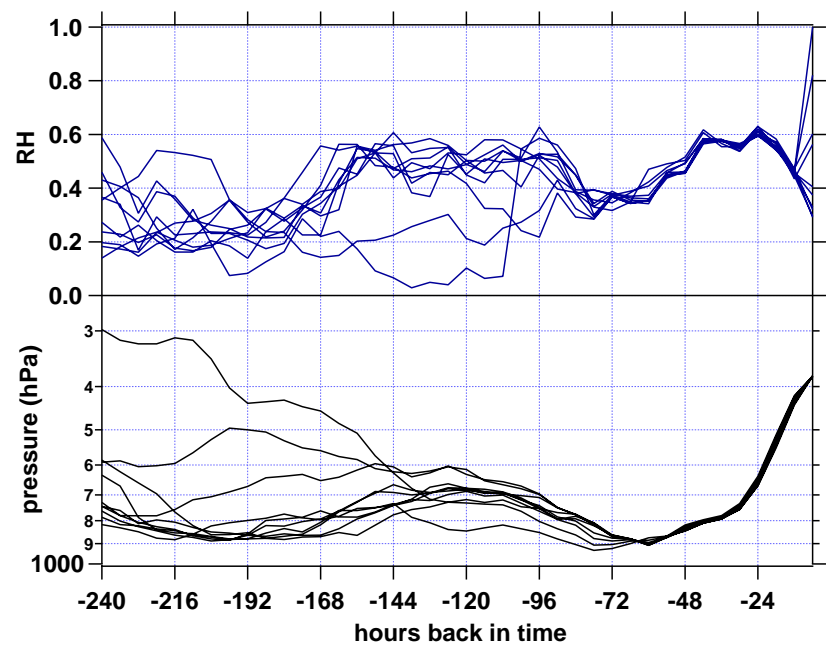

Fig. 9. Pressure and relative humidity along back trajectories calculated with the OFFLINE model for every minute during plume II. The data points at $0 \mathrm{~h}$ represent in-situ measurements.

air masses were subject to a strong and rapid uplift within 23 days and a humidity loss in the last $24 \mathrm{~h}$. In-situ measured relative humidity was between 29 and $32 \%$ in the maximum of the pollution episode and up to $100 \%$ when entering and leaving the plume (Fig. 9 upper panel). A low pressure system travelled from the North American east coast to the west coast of Greenland between 6 and 8 July (see Fig. 2). The enhanced pollution in the warm sector of the cyclone and the above described trajectory analyses suggest that the pollution plume was carried upwards by a warm conveyor belt (WCB). Since condensation and precipitation are widespread and intense within the ascending air masses of a WCB the question 
arises, how much of the original particulate pollution remains after the transport to the atmosphere above Greenland. The FLEXPART BC tracer ratio indicates (Fig. 3d) that less than $1 \%$ of the aerosol-like tracer arrived at the point of interception which is true for the entire flight. The detection of Plume II, however, shows that aerosol wash-out in a WCB is not necessarily complete. Also note that the ozone mixing ratio is strongly elevated for the duration of the plume. FLEXPART stratospheric air mass contribution is however $<5 \%$ which is in good agreement with the history of the air mass (Fig. 9) suggesting that photochemical production of ozone may have taken place.

\subsubsection{Stratospheric air mass intrusion into upper tropospheric Asian pollution plume}

While in Plume II the positive $\Delta \mathrm{O}_{3}$ was not due to mixing with stratospheric air masses, the long period of ozone elevation during pollution episode IV on 13 July (Fig. 4) can be associated with a stratospheric air mass intrusion. Even though the modelled 2 PVU isosurface (red line in Fig. 7), an indicator for the location of the dynamical tropopause (Holton et al., 1995), is located at roughly $9 \mathrm{~km}$, FLEXPART calculations show a contribution of 20 to $25 \%$ of stratospheric air masses for this period (not shown). The ozone mixing ratio is clearly enhanced at $145 \mathrm{nmol} \mathrm{mol}^{-1}$ with $\Delta \mathrm{O}_{3}$ being $50 \mathrm{nmol} \mathrm{mol}^{-1}$. CO stays relatively low at $95 \mathrm{nmol} \mathrm{mol}^{-1}$ on average with a $\Delta \mathrm{CO}$ of $-16 \mathrm{nmol} \mathrm{mol}^{-1}$. It is conceivable that elevated plume $\mathrm{CO}$ concentrations might have been cancelled out by the mixing of tropospheric and stratospheric air masses in this case. The in-situ relative humidity drops by $10 \%$ when entering and increases by $10 \%$ when leaving this episode confirming the stratospheric influence. Plume IV forms part of the same pollution episode as Plume V since the aircraft returned along the same coordinates but at different altitudes as can be seen in Fig. 7 by the mirrored structure of the modelled excess $\mathrm{CO}$ passive tracer. Therefore, a similar trend in trace gas enhancements is expected. However, the behaviour is opposite. This shows that the same pollution episode can exhibit very diverse characteristics dependent on where measurements were performed. This is not only true for trace gases but also for the aerosol concentration. While in Plume V particles were scavenged, the SMPS shows in Plume IV an enhanced signal of up to $0.25 \mu \mathrm{m}^{3} \mathrm{~cm}^{-3}$ for accumulation mode particles, and AMS total mass has a mean of $0.98 \pm 0.40 \mu \mathrm{g} \mathrm{m}^{-3}, 1.45$ times higher than the average of mass concentrations of plumes encountered during the campaign (see Sect. 5). The fraction of organic mass is $52 \pm 22 \%$. According to the FLEXPART column-integrated emission sensitivity (Fig. 6a), the sampled air masses arrived from Siberia (BB) and East Asia (FF from the Beijing area, Korea and Japan). The FLEXPART CO passive fire tracer contribution ranges between 54 and $90 \%$ of the total CO contribution during this episode (Fig. 4c). This is only partly consistent with the AMS findings since the large fraction of particulate sulphate $(48 \pm 22 \%)$ reflects a strong FF contribution rather than BB. The plume age varied over the sampling period from about 11 to 16 days (see Fig. 6a). Air masses extending over the middle and upper troposphere (300 and $700 \mathrm{hPa}$ ) moved from southern Siberia and East Asia over the North Pole (Sodemann et al., 2010; Roiger et al., 2011). $72 \mathrm{~h}$ prior to the encounter all trajectories were above $430 \mathrm{hPa}$ at $79^{\circ} \mathrm{N}$ from where they travelled south to the point of interception. As back trajectory analyses with the OFFLINE model suggest, this pollution episode might be related to the case study presented by Roiger et al. (2011). They describe how anthropogenic East Asian polluted air masses were uplifted in a WCB entering the lowermost Arctic stratosphere with subsequent crosspolar transport towards Greenland. The pollutant rich tropospheric streamer and ozone rich stratospheric air masses seem to have irreversibly mixed at the filamented edges of the intrusion. While the latitudinal coordinates of the event described in Roiger et al. (2011) and of Plume IV coincide very well, there is a difference in roughly $5^{\circ}$ longitude and up to $200 \mathrm{hPa}$ in the vertical. A comparison of both plumes, however, is out of scope for this paper.

Altogether, this discussion of only six detected plumes shows the large variability in characteristics of pollution reaching Greenland during summer. At the beginning of July 2008, an intense low pressure system moving from North America towards southern Greenland was responsible for the advection of US American and Canadian polluted air masses with transport times between three and nine days. Later, two low pressure systems, one over the East Siberian Sea and another at the east coast of Greenland, facilitated crosspolar transport of East Asian and Siberian air masses towards Greenland where the transport time was roughly between two and three weeks. For the general evaluation of long-range transport pollution the observed cases show that both gaseous and particulate tracers need to be taken into account. Trace gases might not always be elevated when aerosol pollution is present (Plume III). Also, air mass uplift in WCB over East Asia led to nearly complete aerosol scavenging (Plume $\mathrm{V}$ ) while trace gas mixing ratios remained elevated, whereas WCB transport out of North America was responsible for enhanced particulate and gaseous pollution over southern Greenland (Plume II). The high variability of chemical characteristics was even true within the same pollution episode as cases IV and V show.

\section{General characterisation of summertime aerosol over Greenland}

\subsection{Vertical profiles}

Figure 10 shows the campaign average vertical profiles of the total AMS measured aerosol mass, the SMPS detected volume of particles, and the mixing ratio of $\mathrm{CO}$ for all flights 


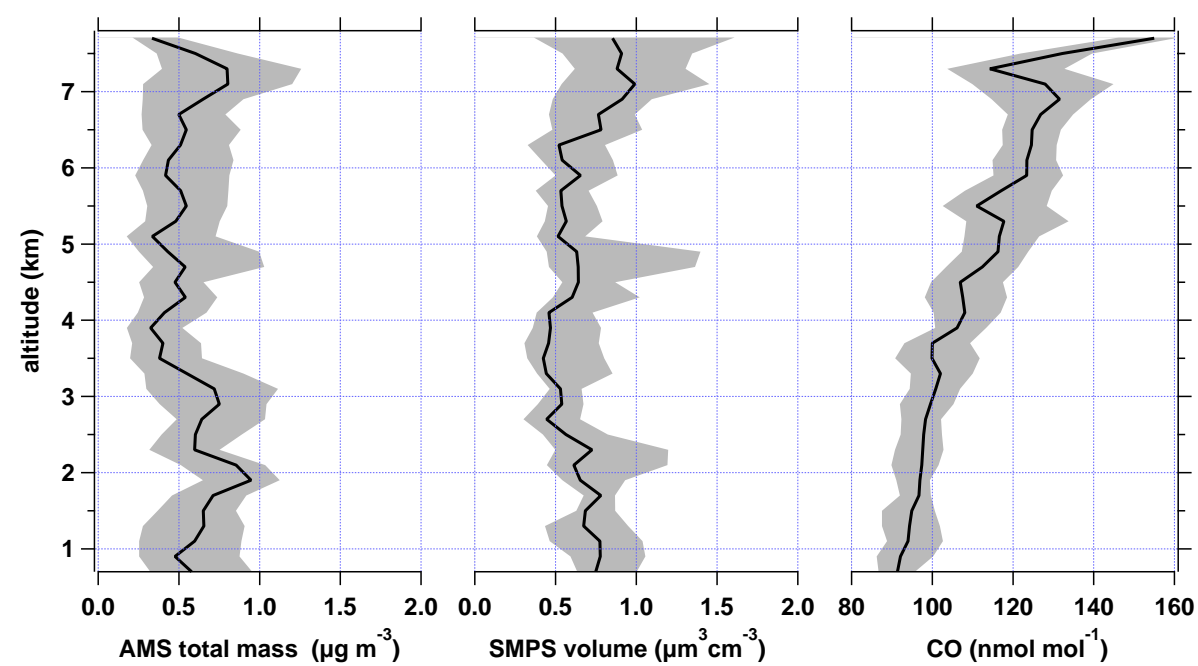

Fig. 10. Vertical profile of total AMS aerosol mass, SMPS aerosol volume, and CO mixing ratio for all 8 POLARCAT flights. The black lines show the median concentration for $200 \mathrm{~m}$ altitude bins while the grey shaded areas comprise the inter-quartile concentrations. The data has been smoothed by a sliding average comprising 5 altitude bins. Aerosol mass and volume are given in STP.

indicated in Table 2. The black lines denote the median values of $200 \mathrm{~m}$ altitude bins while the grey shaded areas constrain the inter-quartiles. No real boundary layer enhancement in particles over land and inland ice was found as reported previously by other authors for summertime Arctic measurements at the surface (e.g. Engvall et al., 2008), while in the marine boundary layer a maximum of $1.22 \pm 0.30 \mu \mathrm{g} \mathrm{m}^{-3}$ consisting of $50 \%$ sulphate aerosol was detected. Between 1 and $3 \mathrm{~km}$ a slight enhancement in aerosol volume and two distinct elevations in aerosol mass were observed which originated from low-level pollution transport out of North America (see discussion of flight from 8 July in Sect. 4.1). In the free troposphere, from above 3 to $5.5 \mathrm{~km}$ aerosol loadings are at a minimum with a mass median mainly below $0.5 \mu \mathrm{g} \mathrm{m}^{-3}$ and an aerosol volume of below $0.50 \mu \mathrm{m}^{3} \mathrm{~cm}^{-3}$. Based on the increase of the CO mixing ratio with altitude, advection of polluted air masses can be assumed. Thus, higher aerosol concentrations could be expected. Since this is not the case, wet deposition is a likely explanation for the low aerosol concentration. This finding is comparable to measurements over the UK yeararound (Morgan et al., 2009) and Central and Western Europe from May and late October/early November (Schneider et al., 2006a; Schmale et al., 2010) where similar aerosol concentrations were measured. According to these data the free troposphere over Greenland is not significantly cleaner than over Europe in terms of aerosol mass concentrations. Above $5.5 \mathrm{~km}$ aerosol mass increases slightly, as well as the $\mathrm{CO}$ mixing ratio. This might reflect the high altitude longrange transport of polluted air masses from North America, Siberia/Asia and Europe.

In general, the non-plume aerosol is composed of $29 \pm 20 \%$ particulate sulphate and $71 \pm 20 \%$ organic car- bon, while particulate nitrate, ammonium, and chloride are all below detection limit. Including a maximum estimate of nitrate and ammonium mass concentrations based on the average LOD from all flights, sulphate aerosol would make up approximately $15 \%$ of the particle mass and organics $56 \%$, not taking into account species like BC or dust which the AMS cannot measure. For pollution episodes with mass loadings greater than $1.00 \mathrm{\mu g} \mathrm{m}^{-3}$ the organic mass fraction increases to $78 \pm 12 \%$ and even to $85 \pm 12 \%$ for events with more than $2.00 \mu \mathrm{g} \mathrm{m}^{-3}$. This means that pollution transport enhances the organic carbon mass loading in the free troposphere above Greenland. In terms of mass concentration, during plume events the median loading increases from 0.48 to $0.58 \mu \mathrm{g} \mathrm{m}^{-3}$.

If a particle density of $1.7 \mathrm{~g} \mathrm{~cm}^{-3}$ is assumed, based on densities of sulphate/sulphuric acid $\left(1.7-1.8 \mathrm{~g} \mathrm{~cm}^{-3}\right)$ and aged organic matter (1.5-1.7 $\mathrm{g} \mathrm{cm}^{-3}$, Dinar et al., 2006), the SMPS particle volume $\left(\mu \mathrm{m} \mathrm{cm}^{-3}\right)$ is roughly a factor 2 too high. This can partly be explained by the fraction of particles which the SMPS can detect but which are not accounted for by the AMS. As not $50 \%$ of the mass is composed of $\mathrm{BC}$, mineral dust or refractory organics, the uncertainties in the AMS data due to the total estimated collection efficiency $\mathrm{CE}_{\mathrm{PCI}}$ of $27 \%$ and the systematic $30 \%$ uncertainty in the PCI inlet transmission are more important. Furthermore, the aerosol number and size distributions were most likely not stable during one SMPS scan of $130 \mathrm{~s}$ adding uncertainties to the aerosol volume size distribution (see also Quennehen et al., 2011). The SMPS data quality has been proven (see Quennehen et al., 2011) by the very good consistency of independent data sets of size distributions from SMPS and PCASP, total concentrations from CPC 3010, and light scattering from the TSI nephelometer. 
Table 5. Emission ratios of gaseous sulphur and gaseous organic compounds from fossil fuel (FF) and biomass burning (BB) based on several emission inventories and studies.

\begin{tabular}{|c|c|c|c|c|}
\hline \multirow[t]{2}{*}{ Reference } & \multicolumn{2}{|c|}{ Fossil fuel combustion } & \multicolumn{2}{|c|}{ Biomass burning } \\
\hline & $\mathrm{SO}_{2} / \mathrm{CO}$ & $\mathrm{VOC} / \mathrm{CO}$ & $\mathrm{SO}_{2} / \mathrm{CO}$ & $\mathrm{VOC} / \mathrm{CO}$ \\
\hline EDGAR $32 \mathrm{FT} 2000^{1}$ & $0.30-0.45$ & - & - & - \\
\hline Streets et al. $(2003)^{2}$ & 0.16 & 0.19 & 0.007 & 0.18 \\
\hline Zhang et al. $(2009)^{3}$ & 0.16 & 0.18 & - & 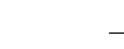 \\
\hline Andreae and Merlet $(2001)^{4}$ & - & - & 0.009 & 0.05 \\
\hline Wiedinmyer et al. $(2006)^{5}$ & - & - & 0.0004 & 0.004 \\
\hline Yokelson et al. (2009) ${ }^{6}$ & - & - & - & 0.04 \\
\hline Neto et al. $(2009)^{7}$ & - & - & - & 0.05 \\
\hline
\end{tabular}

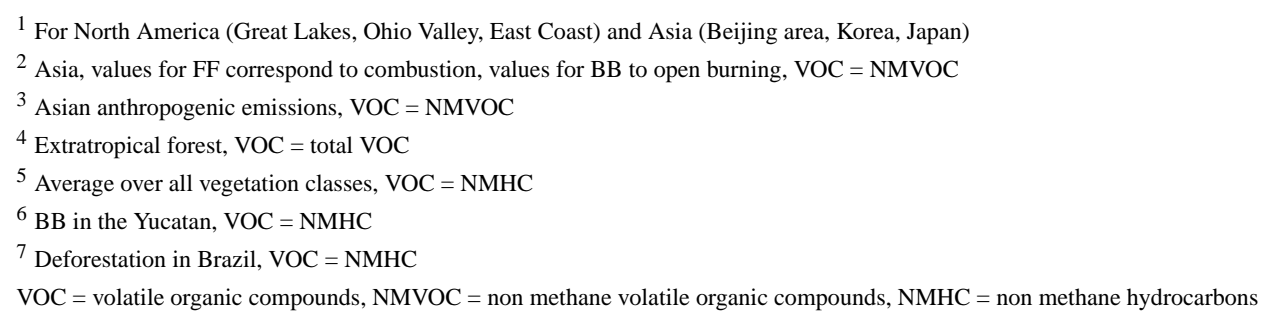

\subsection{Chemical plume properties}

The FLEXPART analysis revealed that the major source contributions from NA were from BB events in Saskatchewan, Canada, and FF in the Great Lakes area, and Ohio Valley. European sources were mostly of anthropogenic nature, while a second BB influence originated from the Yakutsk area (Paris et al., 2009) in Siberia usually mixed with anthropogenic emissions from East Asia. While European and NA pollution was detected between 60 and $71^{\circ} \mathrm{N}$, Siberian/Asian plumes were only observed north of $66^{\circ}$. A total of 48 plumes were detected with the AMS during POLARCAT and categorised into five different classes. The plume identification method was described in Sect. 4. The five categories were established based on a plume by plume analysis in which the FLEXPART column-integrated emission sensitivity, the general footprint tracer, and the $\mathrm{CO}, \mathrm{CO}$ fire, $\mathrm{BC}$ and $\mathrm{SO}_{2}$ tracer contributions were taken into account. First, 13 subclasses were established and then comprehended in 5 categories to obtain more robust statistics for each class (see Table 3).

\subsubsection{Identification of emission sources by aerosol chemical composition}

With the AMS chemical composition measurements it was possible to discriminate the different categories of plumes by determining the ratio of particulate sulphate and organic matter to total aerosol mass determined by the AMS measurements. Data from emission studies and inventories (see Table 5) suggest that FF plumes are marked by higher sulphur emissions while BB pollution is characterised by organic vapours which in the process of ageing condense on particles due to their decreasing vapour pressures. FF emissions have more than one order of magnitude higher $\mathrm{SO}_{2} / \mathrm{CO}$ emissions ratios than $\mathrm{BB}$ while $\mathrm{BB}$ organic vapour emission ratios are roughly ten times higher than their $\mathrm{SO}_{2} / \mathrm{CO}$ emissions (Streets et al., 2003; Zhang et al., 2009; Andreae and Merlet, 2001; Wiedinmyer et al., 2006). Thus, organic carbon aerosol is expected to dominate in BB plumes whereas sulphate aerosol is associated with FF pollution. Yokelson et al. (2009) report 67 times higher concentration of particulate carbon to sulphate measured by an AMS in relatively young BB plumes. Also Shinozuka et al. (2010) report on high ratios of organics to particulate sulphate for $\mathrm{BB}$ plumes measured by an AMS over Alaska during ARCTAS spring 2008. Young BB mass spectra can be identified by the ratio of certain markers $(\mathrm{m} / \mathrm{z}, 60$ and $\mathrm{m} / \mathrm{z}, 73$, Schneider et al., 2006b, Alfarra et al., 2007) for levoglucosan, which is a thermal decomposition product of cellulose (Simoneit et al., 1999). However, the long-range transport plumes observed over Greenland were photochemically processed to a very high degree and thus levoglucosan is expected to be decomposed (Hennigan et al., 2010). Figure 11a shows the derived sulphate and organic carbon ratios for the five different types of plumes. The categories start from the left with "pure" BB while the anthropogenic and Asian factors increase towards the right. At the very right the data for nonplume periods are displayed. The term "pure" is put in quotation marks as we cannot exclude mixtures with other air masses. "Pure" BB plumes, category one, are characterised by a median sulphate fraction of 0.22 , which is also true for the second plume type, a mixture of prevailing $\mathrm{BB}$ and little FF from NA and Europe with no influence from Asia. This is consistent with findings by Heald et al. (2008) who 

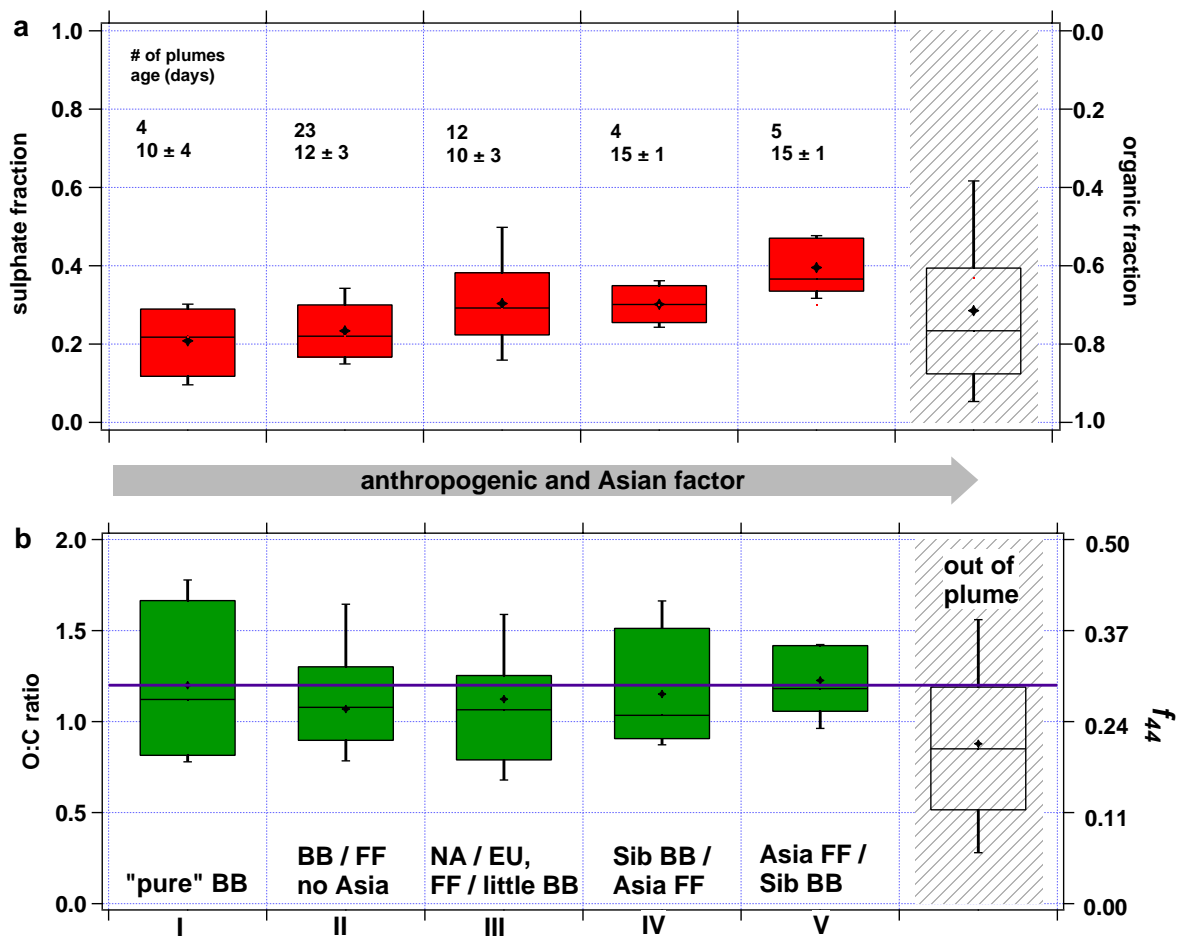

Fig. 11. (a) Fraction of particulate sulphate/organics associated with the type of pollution plume, and measurement periods without plume influence. The boxes denote the 25th and 75th percentiles, the black line within the box represents the median and the error bars show the 10th and 90th percentiles. The black stars denote the average value. (b) Oxygen to carbon ratio (O:C ratio), same notation as top panel, $f_{44}$ denotes the fraction of $\mathrm{m} / \mathrm{z} 44$ of total organic mass. The purple line shows the oxygenation maximum after $\mathrm{Ng}$ et al. (2010). The roman numbers identify the plume categories.

also report around $20 \%$ of sulphate for BB plumes, Singh et al. (2010) who found roughly $17 \%$ for aged (1-5 days) BB/FF plumes from North America during ARCTAS spring and summer, and Brock et al. (2010) reporting on $26 \%$ particulate sulphate during ARCPAC (Aerosol, Radiation, and Cloud Processes affecting Arctic Climate) 2008, accounting only for contributions from particulate sulphate and organics. It has been observed that in ageing BB plumes the relative increase in mass of particulate sulphate is higher than of organic carbon (Formenti et al., 2003; Yokelson et al., 2009) which can explain the relatively high percentage of sulphate in the detected BB plumes over Greenland. Enhanced particulate sulphate fractions in aged forest fire plumes have been reported before (Hudson et al., 2004). Within the third class, FF dominated plumes from the same source regions, the median sulphate fraction rises to 0.29 , similar to plumes characterised mainly by Siberian BB and little Asian anthropogenic influence (0.30). Asian fossil fuel dominated plumes with little Siberian BB contribution reach a sulphate fraction of 0.37. This shows that the major contribution of particulate sulphate and thus acidic aerosol originates from East Asian anthropogenic activity. The highest concentration of particulate sulphate throughout the POLARCAT campaign was $1.95 \pm 0.12 \mu \mathrm{g} \mathrm{m}^{-3}$ observed in an Asian fossil fuel influ- enced plume on 14 July. This is consistent with observations of Asian industrial plume transport and evolution out of $\mathrm{NE}$ China (Li et al., 2010). Lu et al. (2010) report that the annual growth rate of $\mathrm{SO}_{2}$ emissions from China was $7.3 \%$ between 2000 and 2006. The main contribution was from Northern China power plants which almost doubled their $\mathrm{SO}_{2}$ emissions in this period. During the POLARCAT campaign no "pure" Asian FF plume was observed as East Asian outflow was always mixed with Siberian forest fire influenced air masses. However, it is conceivable that outside of the fire season air masses exclusively characterised by East Asian anthropogenic activity are transported towards Greenland. Therefore, the theoretical composition of a "pure" Asian FF plume can be estimated: The FLEXPART CO passive fire tracer indicates $\mathrm{BB}$ contributions between 54 and $85 \%$ for the respective episodes. From the aerosol composition of category I ("pure" BB) we know that the BB contributions contain roughly $22 \%$ particulate sulphate. Based on this, a percentage of $88.7 \pm 34.5 \%$ of particulate sulphate is estimated for a "pure" Asian FF plume. Siberian fires are estimated to contribute more than $56 \%$ of Northern Hemispheric CO from extra tropical BB (van der Werf et al., 2006). However, during the POLARCAT-France summer campaign, it was not found that Siberian BB had a stronger influence on aerosol 


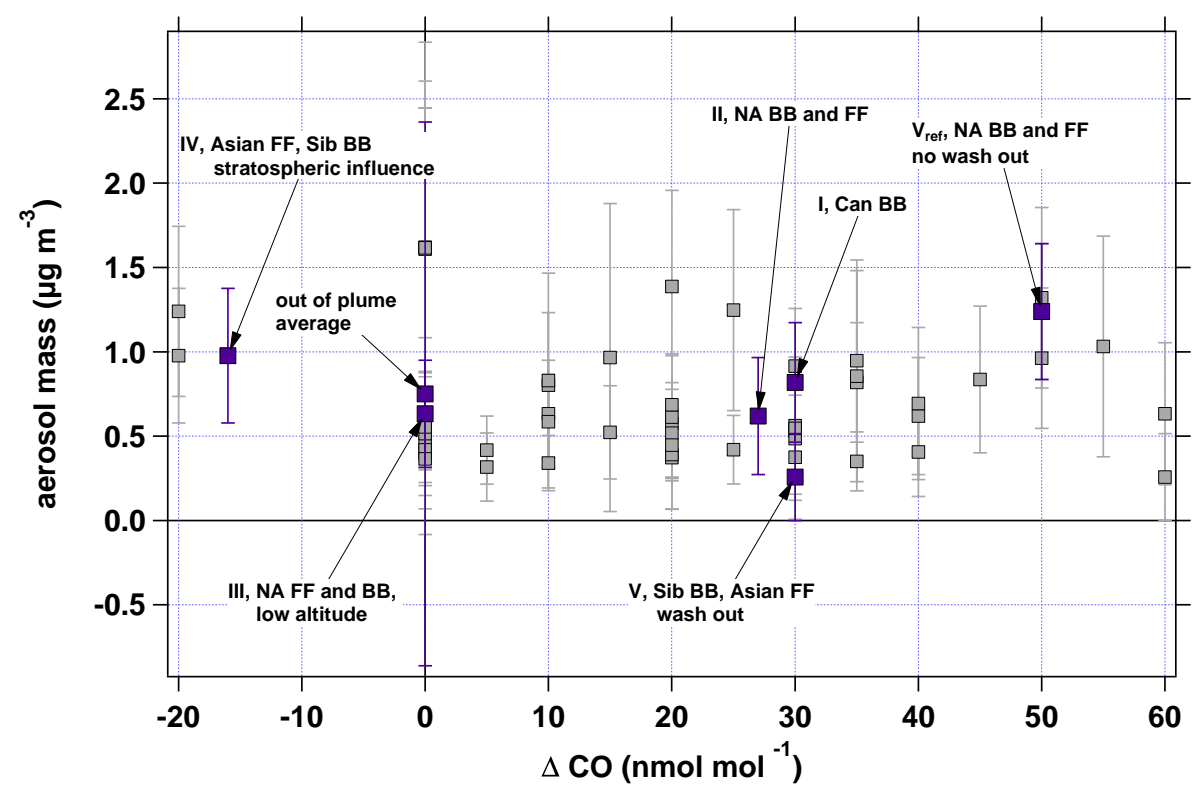

Fig. 12. Total AMS derived aerosol mass versus $\Delta \mathrm{CO}$ for 48 identified pollution plumes and one average non-plume point. The highlighted plumes are discussed in Sect. 4.1.

composition over Greenland than Canadian BB. This might be due on the one hand to the longer transport pathway from Asia, resulting in more complete removal en-route to Greenland, and on the other hand to the meteorological conditions which favoured transport of NA BB plumes. Biomass burning was more active in Saskatchewan, Canada, at the time of this field experiment. If measurements had been conducted earlier in the year, higher Siberian influence could have been observed (Warneke et al., 2010). The median particulate sulphate fraction for non-plume periods is $0.23 \mu \mathrm{g} \mathrm{m}^{-3}$, thus similar to category I and II, however with larger variability.

\subsubsection{O:C ratio of the organic aerosol}

Figure 11a also indicates the average age of a plume class since emission. It was calculated by averaging over the mean age of all individual pollution episodes within one category based on FLEXPART data. FLEXPART calculations derive a so-called age spectrum for each air mass probed by the aircraft for several types of tracers. For the average age calculation of a single plume the $\mathrm{CO}$ passive tracer age spectrum was used (Stohl et al., 2003). Each day's contribution (1 to 20 days back from the time of sampling) was weighted based on the excess $\mathrm{CO}$ mixing ratio per plume and multiplied by the specific day of contribution. The sum over the weighted daily contributions allows for an estimation of the average age of a pollution plume. The plot shows that long-range transport from North America and Europe took roughly 10 days (compare Fig. 5a-d) while plumes from Siberia and Asia generally travelled 15 days or longer (compare Fig. 6a, b). These periods are comparably long for aerosol transport and make par- ticles subject to a variety of processes along the way. Among others these processes include ageing by photochemical processing. The photochemical state of organic aerosol can be derived from the $\mathrm{O}: \mathrm{C}$ ratio (oxygen to carbon). The O:C ratio can be approximated with a unit resolution AMS by determining the ratio of the organic contribution of $\mathrm{m} / \mathrm{z} 44$ to the total organic mass, denoted as $f_{44}$ (Aiken et al., 2008; $\mathrm{Ng}$ et al. 2010). For all types of detected plumes the median and average O:C ratio oscillated between 1.0 and 1.2 which corresponds to LV-OOA (low-volatility oxygenated organic aerosol, Jimenez et al., 2009), thus aged, organic matter (see Fig. 11b). No significant difference within the one standard deviation from the mean between the youngest ( $\sim 3$ day) and oldest ( $\sim 16$ day) plumes within the categories could be found, meaning the organic aerosol component is already highly processed after roughly one week of transport and additional time spent in the free troposphere does not increase the $\mathrm{O}: \mathrm{C}$ ratio significantly. The finding is consistent with results from $\mathrm{Ng}$ et al. (2010) who found an asymptotic trend to an $\mathrm{O}: \mathrm{C}$ ratio of 1.2 with age as indicated by the purple line in Fig. 11b. Furthermore, this implies that the characteristics of the organic aerosol advected to Greenland do not differ much in terms of chemical characteristics despite their distinct origins (shorter travelled particles correspond to NA, longer travelled ones to Siberia and East Asia). The non-plume O:C ratio (median: 0.85, mean: 0.88) implies that the aerosol background is less aged. There is not enough information to draw conclusions on the origin of this aerosol. However, a potential contribution might come from marine emissions of the North Atlantic Ocean. Russell et al. (2010) found that organic aerosol accounts for up to $47 \%$ of the 
submicron particulate mass over the North Atlantic and Arctic Ocean and is dominated by organic hydroxyl groups. As the sea is also a source for sulphur containing aerosol, marine emissions might explain the relatively high sulphate aerosol concentrations for the non-plume periods.

\subsubsection{Correlation between aerosol mass and carbon monoxide mixing ratio}

Due to transport times between 3 and 16 days, the long distance from the source, and aerosol scavenging during transport, especially in WCB events, it was not possible to derive a correlation of total aerosol mass and $\mathrm{CO}$ mixing ratio for plumes arriving at Greenland. In the vicinity of a source, usually a positive correlation between $\mathrm{CO}$ or $\Delta \mathrm{CO}$ and aerosol species, i.e. organic carbon and black carbon, can be observed e.g. (Spackman et al., 2008; Singh et al., 2010; Yokelson et al., 2009). A factor which needs to be taken into account when correlating $\mathrm{CO}$ enhancements with aerosol mass concentrations is that this technique works best when the trace gas enhancement is large compared to the background $\mathrm{CO}$ value. The plumes studied here do not show an intense increase of the $\mathrm{CO}$ mixing ratio and the variability in the background concentrations is difficult to quantify, hence the difficulties in deriving a correlation. Figure 12 displays the measured aerosol mass versus $\Delta \mathrm{CO}$ for all 48 plumes and an average out-of-plume data point. The individual plumes discussed in Sect. 4.1 are highlighted. $\triangle \mathrm{CO}$ varies between -20 and $60 \mathrm{nmol} \mathrm{mol}^{-1}$ while aerosol concentrations cover values between 0 and $2 \mu \mathrm{g} \mathrm{m}^{-3}$ over the whole range. For negative $\Delta \mathrm{CO}$ values the ozone mixing ratio is greater than $130 \mathrm{nmol} \mathrm{mol}^{-1}$ indicating upper tropospheric and lower stratospheric air mass contribution and thus most likely high altitude transport where wet deposition is less probable. Aerosol mass concentration is always larger than $0.97 \mu \mathrm{g} \mathrm{m}^{-3}$ for these cases. For all other plumes it was observed that the measured submicron aerosol mass was composed of at least $30 \%$ organic carbon for CO mixing ratios between 100 and $140 \mathrm{nmol} \mathrm{mol}^{-1}$ and for larger mixing ratios more than $60 \%$ of the mass was organic.

\subsection{Aerosol size distributions}

Size distributions of aerosol number and volume concentrations measured by the SMPS have been averaged for each of the five plume classes and for all out-of-plume periods (see Fig. 13a and b) and fitted with lognormal functions (see Table 6). All size distributions show clear enhancements in the accumulation mode as expected after transport times of one to two weeks (Jaenicke, 1980). The non-plume and "pure BB" size distributions (Fig. 13a, b black and dark green trace, respectively) show a significant enhancement in Aitken mode particles between $24 \pm 1$ and $43 \pm 1$, and $66 \pm 1 \mathrm{~nm}$, respectively, based on the volume. An additional accumulation mode with $490 \pm 446 \mathrm{~nm}$ in background conditions and with $392 \pm 17 \mathrm{~nm}$ for BB perturbed conditions is present. Mainly BB influenced nonAsian air masses (Fig. 13a, b, brown trace) also present two modes at $72 \pm 13 \mathrm{~nm}$ and $287 \pm 384 \mathrm{~nm}$ (volume-based). For a detailed discussion on the North American BB plumes see Quennehen et al. (2011). Air masses with mainly Siberian BB contribution display a broad $\left(\sigma_{\mathrm{g}}=1.92\right)$ one-modal volume size distribution (Fig. 13a, b, bright green trace) with $269 \pm 1 \mathrm{~nm}$. Asian FF dominated plumes again show two modes (red trace) with $83 \pm 9 \mathrm{~nm}$ and $321 \pm 35 \mathrm{~nm}$. Based on this, the background aerosol appears to have the largest geometrical mean diameter in the accumulation mode followed by the non-Asian FF dominated plume $(471 \pm 56 \mathrm{~nm})$ signatures while Siberian BB dominated plumes show a rather small mode diameter comparable to non-Asian BB dominated pollution. Mixed BB and FF plume volume size distributions appear more than $100 \mathrm{~nm}$ smaller in the accumulation mode than "pure" BB. And, FF dominated particle size distributions are larger than those of $\mathrm{BB}$ dominated plumes.

\subsection{Plume age and aerosol lifetime}

The long transport times raise the question of aerosol lifetime. Ideally, particles from the same source region, i.e. similar chemical and hygroscopic properties, and comparable emission strengths at a variety of ages are measured. However, despite the lack of detailed information on the source region and meteorology at the time of emission and thus source strength, it was possible to relate the total measured aerosol mass to the FLEXPART calculated age for 10 plumes. This results in an exponential distribution from which an aerosol lifetime in the range between 7 and 11 days can be derived (Fig. 14, green line). For this calculation dilution and deposition over time were assumed to be similar for the chosen plumes as they have comparable chemical properties making them similarly hydrophilic/hydrophobic. The 10 selected plumes are characterised by mainly NA FF and little BB influence (see bold writing in Table 3). The red cross in Fig. 14 denotes an outlier. OFFLINE back trajectories suggest that this air mass was uplifted in a WCB event like Plume II as discussed in sect. 4.1.5. Furthermore, in-situ measured relative humidity was around $90 \%$. Thus, wet deposition along the pathway and/or in-situ is likely for this case. A $\tau$ ranging from 7 to 11 days is reasonable and consistent with lifetimes determined by other authors. Paris et al. (2009) found an experimental equivalent black carbon lifetime of 5.1 days for Siberian forest fire emissions, Koch and Hansen (2005) a modelled BC lifetime of 7.3 days, and Farina et al. (2010) modelled 6.8 to 16 days for SOA (secondary organic aerosol) depending on the scenario on a global scale. Exponential fits with lifetimes of 5, 7, 9, 11, and 16 days have been added to Fig. 14. 
Table 6. Fit parameters for the log normal number and volume size distributions as shown in Fig. 13.

\begin{tabular}{|c|c|c|c|c|c|c|}
\hline Parameter* & Out-of-plume & "pure" BB & BB/FF no Asia & NA/EU, FF/little BB & Sib BB/Asia FF & Asia FF/Sib BB \\
\hline \multicolumn{7}{|c|}{$d N / d \ln (d p)$} \\
\hline$N_{0}$ & $2228 \pm 67$ & $1275 \pm 3$ & $596 \pm 252$ & $479 \pm 92$ & $855 \pm 1$ & $308 \pm 48$ \\
\hline \multirow{2}{*}{$\sigma_{\mathrm{g} 0}$} & $1.12 \pm 1.02$ & $1.46 \pm 1.02$ & $1.48 \pm 1.16$ & $1.46 \pm 1.13$ & $1.92 \pm 1.01$ & $1.51 \pm 1.10$ \\
\hline & $0.023 \pm 0.001$ & $0.043 \pm 0.001$ & $0.045 \pm 0.012$ & $0.042 \pm 0.003$ & $0.075 \pm 0.001$ & $0.050 \pm 0.009$ \\
\hline$N_{1}$ & $1153 \pm 171$ & $637 \pm 3$ & $530 \pm 397$ & $780 \pm 72$ & & $605 \pm 34$ \\
\hline \multirow[t]{2}{*}{$\sigma_{\mathrm{g} 1}$} & $1.22 \pm 1.08$ & $1.76 \pm 1.06$ & $1.76 \pm 1.90$ & $2.04 \pm 1.26$ & & $1.78 \pm 1.14$ \\
\hline & $0.039 \pm 0.002$ & $0.150 \pm 0.017$ & $0.110 \pm 0.111$ & $0.102 \pm 0.048$ & & $0.117 \pm 0.033$ \\
\hline$N_{2}$ & $1344 \pm 913$ & & & & & \\
\hline \multirow[t]{2}{*}{$\sigma_{\mathrm{g} 2}$} & $2.35 \pm 2.12$ & & & & & \\
\hline & $0.054 \pm 0.083$ & & & & & \\
\hline \multicolumn{7}{|c|}{$d V / d \ln (d p)$} \\
\hline$V_{0}$ & $0.02 \pm 6 \times 10^{-4}$ & $0.08 \pm 2 \times 10^{-4}$ & $0.04 \pm 0.02$ & $0.01 \pm 2 \times 10^{-3}$ & $1.29 \pm 2 \times 10^{-4}$ & $0.03 \pm 4 \times 10^{-3}$ \\
\hline \multirow[t]{2}{*}{$\sigma_{\mathrm{g} 0}$} & $1.12 \pm 1.02$ & $1.46 \pm 1.02$ & $1.48 \pm 1.16$ & $1.46 \pm 1.13$ & $1.92 \pm 1.01$ & $1.51 \pm 1.10$ \\
\hline & $0.024 \pm 0.001$ & $0.066 \pm 0.001$ & $0.072 \pm 0.013$ & $0.065 \pm 0.003$ & $0.269 \pm 0.001$ & $0.083 \pm 0.009$ \\
\hline$V_{1}$ & $0.05 \pm 7 \times 10^{-3}$ & $4.81 \pm 3 \times 10^{-2}$ & $1.55 \pm 1.16$ & $4.35 \pm 0.40$ & & $2.33 \pm 0.13$ \\
\hline \multirow[t]{2}{*}{$\sigma_{\mathrm{g} 1}$} & $1.22 \pm 1.08$ & $1.76 \pm 1.06$ & $1.76 \pm 1.90$ & $2.04 \pm 1.26$ & & $1.78 \pm 1.14$ \\
\hline & $0.043 \pm 0.002$ & $0.392 \pm 0.017$ & $0.287 \pm 0.384$ & $0.471 \pm 0.056$ & & $0.321 \pm 0.035$ \\
\hline$V_{2}$ & $2.99 \pm 2.03$ & & & & & \\
\hline \multirow[t]{2}{*}{$\sigma_{\mathrm{g} 2}$} & $2.35 \pm 2.12$ & & & & & \\
\hline & $0.490 \pm 0.446$ & & & & & \\
\hline
\end{tabular}

* fit function:

$\frac{d X}{d \log (d p)}=\sum_{i=0}^{n} \frac{X}{\sqrt{2 \pi} \cdot \ln \left(\sigma_{\mathrm{g}_{i}}\right)} \cdot \exp \left\{-\left(\frac{\left(\ln \frac{d p}{d p_{i}}\right)^{2}}{2 \cdot\left(\ln \left(\sigma_{\mathrm{g}_{i}}\right)\right)^{2}}\right)\right\}$

with $X$ standing for either $N$ (number) or $V$ (volume), $d p$ as particle mobility diameter in $\mu \mathrm{m}, \overline{d p_{i}}$ is the geometrical mean diameter in $\mu$ m of the respective mode, and $\sigma_{\mathrm{g}_{i}}$ is the geometric standard deviation of each mode.

Units of $\frac{d N}{d \ln (d p)}$ are $\mathrm{cm}^{-3}$, and for $\frac{d V}{d \ln (d p)} \mu \mathrm{m}^{-3} \mathrm{~cm}^{-3}$.

\section{Summary and conclusions}

Airborne mass spectrometric measurements during POLARCAT-France summer provided new data on the chemical composition of submicron aerosol in the free troposphere over Greenland. During eight flights aboard the ATR-42 a high variety of pollution episodes originating from North America, Siberia and Asia, and Europe were observed. Emissions from extensive biomass burnings in Siberia, and Canada, and fossil fuel combustion in the United States, East Asia and Europe were transported to Greenland. Even though summertime weather conditions facilitate aerosol wash-out, 48 long-range transport pollution plumes were identified. Transport out of eastern North America happened in various weather patterns including low-level transport below $700 \mathrm{hPa}$ reaching southern Greenland, mid-tropospheric transport, and uplift in WCBs. Although WCB events are associated with precipitation, aerosol was not necessarily removed completely as observed during the flight on 8 July. Emissions from Eurasia were transported in the middle and upper troposphere where aerosol scavenging is weaker and thus particle lifetimes increase. Transport times varied from 3 to 16 days whereas emissions from NA arrived roughly within one week and from Siberia/Asia within two weeks. A particle lifetime in the range between 7 to 11 days was calculated.

Depending on the type of emission, a distinct particle chemical composition is expected. AMS measurements confirm previous studies (Heald et al., 2008) and results from ARCTAS and ARCPAC campaigns (Singh et al., 2010; Shinozuka et al., 2010; Brock et al., 2010) by determining an enhancement of the particulate sulphate mass fraction with increasing influence from anthropogenic and Asian emissions of up to 0.37 compared to 0.22 for aged "pure" BB plumes (see Fig. 11a). The organic carbon fraction in aerosol increases from $71 \%$ for non-plume concentrations to $85 \%$ during strong pollution episodes implying that long-range pollution transport contributes significantly to the mass of organic carbon over Greenland. The photochemical age of organic aerosol, determined as O:C ratio, was found to oscillate 

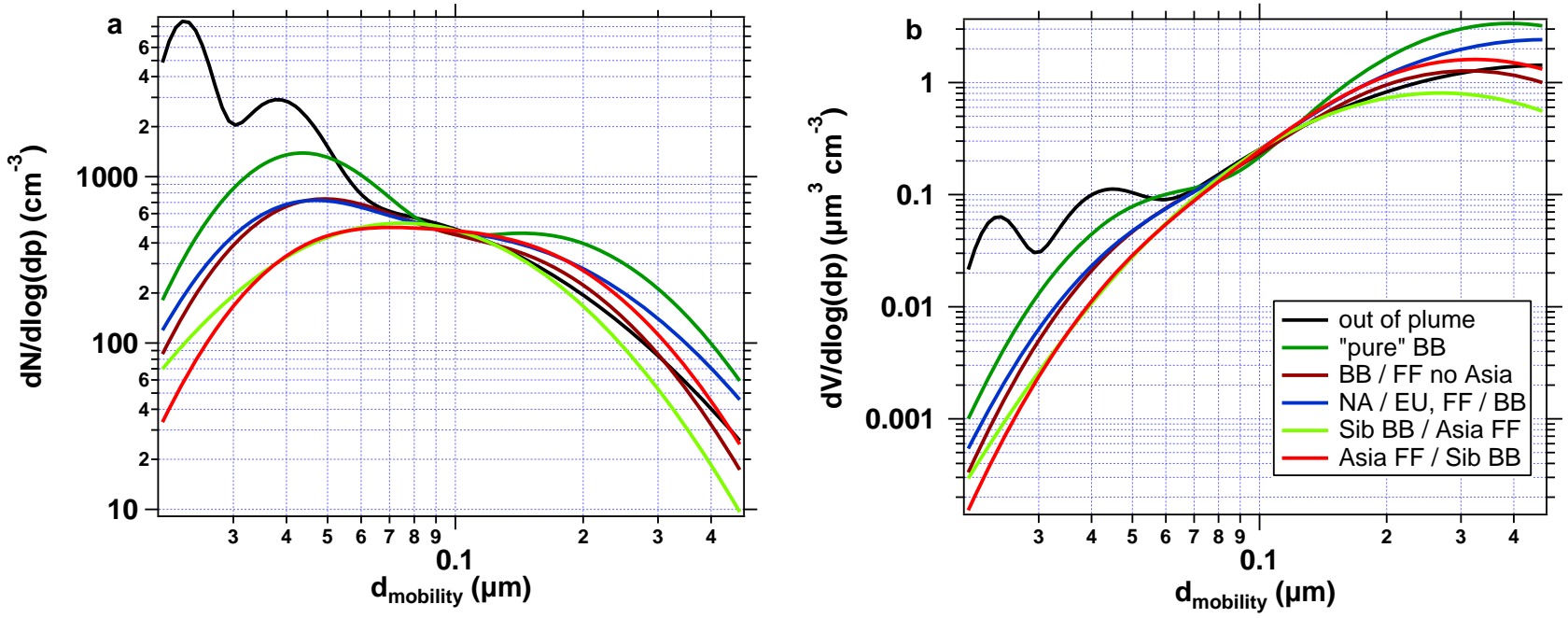

Fig. 13. Lognormal fits for SMPS number (a) and volume (b) size distributions for all five plume categories and all non-plume periods.

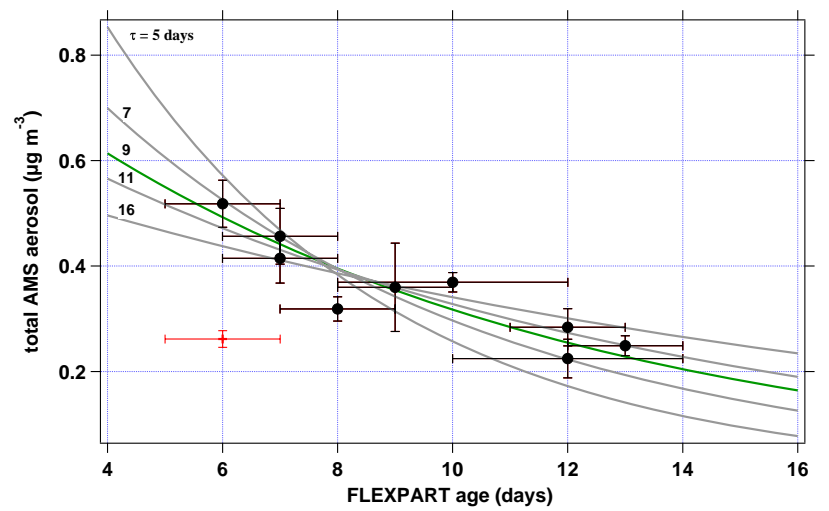

Fig. 14. Lifetime estimation of accumulation mode non-refractory aerosol originating from North American fossil fuel combustion and biomass burning: the horizontal bars represent the standard deviation of the average FLEXPART plume age, the vertical bars the standard deviation within the AMS data of the specific plume. The green line denotes an exponential fit with a $\tau$ between 7 and 11 days. The grey lines represent fits to the data with lifetimes as found in other Arctic aerosol studies (Paris et al., 2009; Koch and Hansen, 2005; Farina et al., 2010). The red cross illustrates an outlier.

around 1.0. This means consequently that the ageing process during the long transport times in the free and upper troposphere produces a uniform low-volatility oxygenated organic aerosol despite different emission source types and regions. Snow sample analysis of organic carbon at Summit, Greenland, confirms the high state of oxygenation of longrange transport aerosol. In general, during the POLARCAT summer campaign, submicron non-refractory aerosol mass $\left(0.5 \mu \mathrm{g} \mathrm{m}^{-3}\right)$ in the free troposphere did not differ substantially from concentrations over Central and Western Europe, showing that even in summer when aerosol scavenging dur- ing long-range transport is expected the Arctic atmosphere is strongly perturbed.

The calculation of number size distributions for each individual plume category showed that "pure" BB aerosol has a dominant contribution from Aitken mode particles.

These results give a valuable insight into the particle chemical composition of the summertime Greenland troposphere. However various questions remain unanswered. Aircraft measurements can only provide very limited data in space and time. Therefore, the detected pollution plumes are highly selective and mass loadings depend on where within a plume they were recorded. Additionally, the composition of advected pollution is highly variable from year to year as biomass burning regions and intensities change annually. Thus, it is difficult to estimate whether Greenland is impacted rather by FF or BB emissions in summer. Furthermore, the distribution of source regions depends strongly on meteorological conditions which influence the transport pathways, and thus arrival altitude, and the precipitation events. Another aspect which was not considered in this work is the question if, where, and how the observed particles will enter and/or leave the Arctic. While it is likely that the measured low-level pollution in clouds on 8 July precipitated in southern Greenland, the fate of upper tropospheric pollution is unknown. Therefore, airborne measurements should be linked with surface atmospheric measurements and used to evaluate modelling studies.

Acknowledgements. We acknowledge funding by the German Research Foundation (DFG) through the SPP 1294, by the State"Exzellenzcluster Geocycles" of Rheinland-Pfalz, and by the Max Planck Society.

POLARCAT-France gratefully acknowledges funding from the following French research agencies - ANR, CNES, CNRS-INSU, IPEV and EUFAR. French researchers also acknowledge financial 
support from the CNRS-INSU CLIMSLIP project. NILU researchers were supported by the Norwegian Research Council in the framework of POLARCAT-Norway.

Special thanks go to the SAFIRE team together with DT-INSU and to Marco Brands, Thomas Böttger, Wilhelm Schneider, and Sören Zorn for technical support before and during the campaign. The authors also would like to thank their colleagues Andreas Minikin and Bernadett Weinzierl from DLR for fruitful discussions.

The service charges for this open access publication have been covered by the Max Planck Society.

Edited by: P. Monks

\section{References}

Aiken, A. C., Decarlo, P. F., Kroll, J. H., Worsnop, D. R., Huffman, J. A., Docherty, K. S., Ulbrich, I. M., Mohr, C., Kimmel, J. R., Sueper, D., Sun, Y., Zhang, Q., Trimborn, A., Northway, M., Ziemann, P. J., Canagaratna, M. R., Onasch, T. B., Alfarra, M. R., Prevot, A. S. H., Dommen, J., Duplissy, J., Metzger, A., Baltensperger, U., and Jimenez, J. L.: O/C and OM/OC ratios of primary, secondary, and ambient organic aerosols with highresolution time-of-flight aerosol mass spectrometry, Environ. Sci. Technol., 42, 4478-4485, doi:10.1021/es703009q, 2008.

Allan, J. D., Jimenez, J. L., Williams, P. I., Alfarra, M. R., Bower, K. N., Jayne, J. T., Coe, H., and Worsnop, D. R.: Quantitative sampling using an Aerodyne aerosol mass spectrometer. 1. Techniques of data interpretation and error analysis, J. Geophys. Res., 108, 4090, doi:10.1029/2002jd002358, 2003.

Allan, J. D., Bower, K. N., Coe, H., Boudries, H., Jayne, J. T., Canagaratna, M. R., Millet, D. B., Goldstein, A. H., Quinn, P. K., Weber, R. J., and Worsnop, D. R.: Submicron aerosol composition at Trinidad Head, California, during ITCT 2K2: Its relationship with gas phase volatile organic carbon and assessment of instrument performance, J. Geophys. Res., 109, D23s24, doi:10.1029/2003jd004208, 2004a.

Allan, J. D., Delia, A. E., Coe, H., Bower, K. N., Alfarra, M. R., Jimenez, J. L., Middlebrook, A. M., Drewnick, F., Onasch, T. B., Canagaratna, M. R., Jayne, J. T., and Worsnopf, D. R.: A generalised method for the extraction of chemically resolved mass spectra from aerodyne aerosol mass spectrometer data, J. Aerosol. Sci., 35, 909-922, doi:10.1016/j.jaerosci.2004.02.007, 2004b.

Alfarra, M. R., Prevot, A. S. H., Szidat, S., Sandradewi, J., Weimer, S., Lanz, V. A., Schreiber, D., Mohr, M., and Baltensperger, U.: Identification of the Mass Spectral Signature of Organic Aerosols from Wood Burning Emissions, Environ. Sci. Technol., 41, 5770-5777, 2007.

AMAP Assessment 2006: Acidifying pollutants, arctic haze, and acidification in the Arctic, Arctic Monitoring and Assessment Programm (AMAP), Oslo, Norway, 2006.

Ancellet, G. and Ravetta, F.: On the usefulness of an airborne lidar for O-3 layer analysis in the free troposphere and the planetary boundary layer, J. Environ. Monit., 5, 47-56, doi:10.1039/b205727a, 2003.

Ancellet, G., Leclair de Bellevue, J., Mari, C., Nedelec, P., Kukui, A., Borbon, A., and Perros, P.: Effects of regional-scale and con- vective transports on tropospheric ozone chemistry revealed by aircraft observations during the wet season of the AMMA campaign, Atmos. Chem. Phys., 9, 383-411, doi:10.5194/acp-9-3832009, 2009.

Andreae, M. O. and Merlet, P.: Emission of trace gases and aerosols from biomass burning, Global Biogeochem. Cy., 15, 955-966, 2001.

Bahreini, R., Dunlea, E. J., Matthew, B. M., Simons, C., Docherty, K. S., DeCarlo, P. F., Jimenez, J. L., Brock, C. A., and Middlebrook, A. M.: Design and operation of a pressure-controlled inlet for airborne sampling with an aerodynamic aerosol lens, Aerosol Sci. Technol., 42, 465-471, doi:10.1080/02786820802178514, 2008.

Bond, T. C., Anderson, T. L., and Campbell, D.: Calibration and intercomparison of filter-based measurements of visible light absorption by aerosols, Aerosol Sci. Technol., 30, 582-600, 1999.

Bond, T. C., Streets, D. G., Yarber, K. F., Nelson, S. M., Woo, J. H., and Klimont, Z.: A technology-based global inventory of black and organic carbon emissions from combustion, J. Geophys. Res., 109, D14203, doi:10.1029/2003jd003697, 2004.

Brock, C. A., Radke, L. F., Lyons, J. H., and Hobbs, P. V.: Arctic hazes in the summer over Greenland and the North-American Arctic. I. Incidence and origins, J. Atmos. Chem., 9, 129-148, 1989.

Brock, C. A., Radke, L. F., and Hobbs, P. V.: Sulfur in particles in the arctic hazes derived from airborne in situ and lidar measurements, J. Geophys. Res., 95, 22369-22387, 1990.

Brock, C. A., Cozic, J., Bahreini, R., Froyd, K. D., Middlebrook, A. M., McComiskey, A., Brioude, J., Cooper, O. R., Stohl, A., Aikin, K. C., de Gouw, J. A., Fahey, D. W., Ferrare, R. A., Gao, R.-S., Gore, W., Holloway, J. S., Hbler, G., Jefferson, A., Lack, D. A., Lance, S., Moore, R. H., Murphy, D. M., Nenes, A., Novelli, P. C., Nowak, J. B., Ogren, J. A., Peischl, J., Pierce, R. B., Pilewskie, P., Quinn, P. K., Ryerson, T. B., Schmidt, K. S., Schwarz, J. P., Sodemann, H., Spackman, J. R., Stark, H., Thomson, D. S., Thornberry, T., Veres, P., Watts, L. A., Warneke, C., and Wollny, A. G.: Characteristics, sources, and transport of aerosols measured in spring 2008 during the aerosol, radiation, and cloud processes affecting Arctic Climate (ARCPAC) Project, Atmos. Chem. Phys., 11, 2423-2453, doi:10.5194/acp-11-24232011, 2011.

Browning, K. A. and G. A. Monk, A simple model for the synoptic analysis of cold fronts, Q. J. Roy. Meteorol. Soc., 108, 435-452, 1982.

Buck, A. L.: Variable-path Lyman-Alpha hygrometer and its operating characteristics, B. Am. Meteorol. Soc., 57, 1113-1118, 1976.

Canagaratna, M. R., Jayne, J. T., Jimenez, J. L., Allan, J. D., Alfarra, M. R., Zhang, Q., Onasch, T. B., Drewnick, F., Coe, H., Middlebrook, A., Delia, A., Williams, L. R., Trimborn, A. M., Northway, M. J., DeCarlo, P. F., Kolb, C. E., Davidovits, P., and Worsnop, D. R.: Chemical and microphysical characterization of ambient aerosols with the aerodyne aerosol mass spectrometer, Mass Spectrom. Rev., 26, 185-222, doi:10.1002/mas.20115, 2007.

Cooper, O. R., Moody, J. L., Parrish, D. D., Trainer, M., Ryerson, T. B., Holloway, J. S., Hubler, G., Fehsenfeld, F. C., and Evans, M. J.: Trace gas composition of midlatitude cyclones over the western North Atlantic Ocean: A conceptual model, J. Geophys. 
Res., 107, 4056, doi:10.1029/2001jd000901, 2002.

Crosier, J., Allan, J. D., Coe, H., Bower, K. N., Formenti, P., and Williams, P. I.: Chemical composition of summertime aerosol in the Po Valley (Italy), northern Adriatic and Black Sea, Q. J. Roy. Meteorol. Soc., 133, 61-75, doi:10.1002/qj.88, 2007.

DeCarlo, P. F., Slowik, J. G., Worsnop, D. R., Davidovits, P., and Jimenez, J. L.: Particle morphology and density characterization by combined mobility and aerodynamic diameter measurements. Part 1: Theory, Aerosol Sci. Technol., 38, 1185-1205, doi:10.1080/027868290903907, 2004.

de Villiers, R. A., Ancellet, G., Pelon, J., Quennehen, B., Schwarzenboeck, A., Gayet, J. F., and Law, K. S.: Airborne measurements of aerosol optical properties related to early spring transport of mid-latitude sources into the Arctic, Atmos. Chem. Phys., 10, 5011-5030, doi:10.5194/acp-10-5011-2010, 2010.

Dickerson, R. R., Li, C., Li, Z., Marufu, L. T., Stehr, J. W., McClure, B., Krotkov, N., Chen, H., Wang, P., Xia, X., Ban, X., Gong, F., Yuan, J., and Yang, J.: Aircraft observations of dust and pollutants over northeast China: Insight into the meteorological mechanisms of transport, J. Geophys. Res., 112, D24S90, doi:D24S90-21-D24S90-D24S90-13, 2007.

Dinar, E., Mentel, T. F., and Rudich, Y.: The density of humic acids and humic like substances (HULIS) from fresh and aged wood burning and pollution aerosol particles, Atmos. Chem. Phys., 6, 5213-5224, doi:10.5194/acp-6-5213-2006, 2006.

Donahue, N. M., Robinson, A. L., and Pandis, S. N.: Atmospheric organic particulate matter: From smoke to secondary organic aerosol, Atmos. Environ., 43, 94-106, doi:10.1016/j.atmosenv.2008.09.055, 2009.

Dreiling, V. and Friederich, B.: Spatial distribution of the Arctic haze aerosol size distribution in western and eastern Arctic, Atmos. Res., 44, 133-152, 1997.

Drewnick, F., Hings, S. S., DeCarlo, P., Jayne, J. T., Gonin, M., Fuhrer, K., Weimer, S., Jimenez, J. L., Demerjian, K. L., Borrmann, S., and Worsnop, D. R.: A new time-of-flight aerosol mass spectrometer (Tof-AMS) - Instrument description and first field deployment, Aerosol Sci. Technol., 39, 637-658, doi:10.1080/02786820500182040, 2005.

Drewnick, F., Hings, S. S., Alfarra, M. R., Prevot, A. S. H., and Borrmann, S.: Aerosol quantification with the Aerodyne Aerosol Mass Spectrometer: detection limits and ionizer background effects, Atmos. Meas. Tech., 2, 33-46, doi:10.5194/amt-2-332009, 2009.

Engvall, A.-C., Krejci, R., Ström, J., Treffeisen, R., Scheele, R., Hermansen, O., and Paatero, J.: Changes in aerosol properties during spring-summer period in the Arctic troposphere, Atmos. Chem. Phys., 8, 445-462, doi:10.5194/acp-8-445-2008, 2008.

Farina, S. C., Adams, P. J., and Pandis, S. N.: Modeling global secondary organic aerosol formation and processing with the volatility basis set: Implications for anthropogenic secondary organic aerosol, J. Geophys. Res., 115, D09202, doi:10.1029/2009jd013046, 2010.

Febvre, G., Gayet, J.-F., Minikin, A., Schlager, H., Shcherbakov, V., Jourdan, O., Busen, R., Fiebig, M., Kärcher, B., and Schumann, U.: On optical and microphysical characteristics of contrails and cirrus, J. Geophys. Res., 114, D02204, doi:10.1029/2008JD010184, 2009.

Flannigan, M. D., Krawchuk, M. A., de Groot, W. J., Wotton, B. M., and Gowman, L. M.: Implications of changing climate for global wildland fire, Int. J. Wildland Fire, 18, 483-507, doi:10.1071/wf08187, 2009.

Formenti, P., Elbert, W., Maenhaut, W., Haywood, J., Osborne, S., and Andreae, M. O.: Inorganic and carbonaceous aerosols during the Southern African Regional Science Initiative (SAFARI 2000) experiment: Chemical characteristics, physical properties, and emission data for smoke from African biomass burning, J. Geophys. Res., 108, 8488, doi:10.1029/2002jd002408, 2003.

Franke, H., Maser, R., Vinnichenko, N., Dreiling, V., Jaenicke, R., Jaeschke, W., and Leiterer, U.: Adaptation of microphysical and chemical instrumentation to the airborne measuring platform Iljushin II-18 'Cyclone' and flight regime planning during the Arctic haze investigation 1993-95, Atmos. Res., 44, 3-16, 1997.

Frost, G. J., McKeen, S. A., Trainer, M., Ryerson, T. B., Neuman, J. A., Roberts, J. M., Swanson, A., Holloway, J. S., Sueper, D. T., Fortin, T., Parrish, D. D., Fehsenfeld, F. C., Flocke, F., Peckham, S. E., Grell, G. A., Kowal, D., Cartwright, J., Auerbach, N., and Habermann, T.: Effects of changing power plant NOx emissions on ozone in the eastern United States: Proof of concept, J. Geophys. Res., 111, D12306, doi:10.1029/2005jd006354, 2006.

Gayet, J. F., Shcherbakov, V., Mannstein, H., Minikin, A., Schumann, U., Strom, J., Petzold, A., Ovarlez, J., and Immler, F.: Microphysical and optical properties of midlatitude cirrus clouds observed in the southern hemisphere during INCA, Q. J. Roy. Meteorol. Soc., 132, 2719-2748, doi:10.1256/qj.05.162, 2006.

Greenaway, K. R.: Experiences with Arctic flying weather, Royal Meteorological Society Canadian Branch (30 November), Toronto, Ontario, 1950.

Hagler, G. S. W., Bergin, M. H., Smith, E. A., Dibb, J. E., Anderson, C., and Steig, E. J.: Particulate and water-soluble carbon measured in recent snow at Summit, Greenland, Geophys. Res. Lett., 34, L16505, doi:10.1029/2007g1030110, 2007.

Hallquist, M., Wenger, J. C., Baltensperger, U., Rudich, Y., Simpson, D., Claeys, M., Dommen, J., Donahue, N. M., George, C., Goldstein, A. H., Hamilton, J. F., Herrmann, H., Hoffmann, T., Iinuma, Y., Jang, M., Jenkin, M. E., Jimenez, J. L., Kiendler-Scharr, A., Maenhaut, W., McFiggans, G., Mentel, Th. F., Monod, A., Prévôt, A. S. H., Seinfeld, J. H., Surratt, J. D., Szmigielski, R., and Wildt, J.: The formation, properties and impact of secondary organic aerosol: current and emerging issues, Atmos. Chem. Phys., 9, 5155-5236, doi:10.5194/acp-95155-2009, 2009.

Heald, C. L., Goldstein, A. H., Allan, J. D., Aiken, A. C., Apel, E., Atlas, E. L., Baker, A. K., Bates, T. S., Beyersdorf, A. J., Blake, D. R., Campos, T., Coe, H., Crounse, J. D., DeCarlo, P. F., de Gouw, J. A., Dunlea, E. J., Flocke, F. M., Fried, A., Goldan, P., Griffin, R. J., Herndon, S. C., Holloway, J. S., Holzinger, R., Jimenez, J. L., Junkermann, W., Kuster, W. C., Lewis, A. C., Meinardi, S., Millet, D. B., Onasch, T., Polidori, A., Quinn, P. K., Riemer, D. D., Roberts, J. M., Salcedo, D., Sive, B., Swanson, A. L., Talbot, R., Warneke, C., Weber, R. J., Weibring, P., Wennberg, P. O., Worsnop, D. R., Wittig, A. E., Zhang, R., Zheng, J., and Zheng, W.: Total observed organic carbon (TOOC) in the atmosphere: a synthesis of North American observations, Atmos. Chem. Phys., 8, 2007-2025, doi:10.5194/acp-82007-2008, 2008.

Hennigan, C. J., Sullivan, A. P., Collett, J. L., and Robinson, A. L.: Levoglucosan stability in biomass burning particles ex- 
posed to hydroxyl radicals, Geophys. Res. Lett., 37, L09806, doi:10.1029/2010g1043088, 2010.

Hings, S. S., Walter, S., Schneider, J., Borrmann, S., and Drewnick, F.: Comparison of a quadrupole and a time-of-flight aerosol mass spectrometer during the Feldberg aerosol characterization experiment 2004, Aerosol Sci. Technol., 41, 679-691, doi:10.1080/02786820701408483, 2007.

Hirdman, D., Sodemann, H., Eckhardt, S., Burkhart, J. F., Jefferson, A., Mefford, T., Quinn, P. K., Sharma, S., Ström, J., and Stohl, A.: Source identification of short-lived air pollutants in the Arctic using statistical analysis of measurement data and particle dispersion model output, Atmos. Chem. Phys., 10, 669-693, doi:10.5194/acp-10-669-2010, 2010.

Holton, J. R., Haynes, P. H., McIntyre, M. E., Douglass, A. R., Rood, R. B., and Pfister, L.: Stratosphere-troposphere exchange, Rev. Geophys., 33, 403-439, 1995.

Hudson, P. K., Murphy, D. M., Cziczo, D. J., Thomson, D. S., de Gouw, J. A., Warneke, C., Holloway, J., Jost, J. R., and Hubler, G.: Biomass-burning particle measurements: Characteristic composition and chemical processing, J. Geosphys. Res., 109, D23s27 doi:10.1029/2003jd004398, 2004.

Huffman, J. A., Jayne, J. T., Drewnick, F., Aiken, A. C., Onasch, T., Worsnop, D. R., and Jimenez, J. L.: Design, modeling, optimization, and experimental tests of a particle beam width probe for the aerodyne aerosol mass spectrometer, Aerosol Sci. Technol., 39, 1143-1163, doi:10.1080/02786820500423782, 2005.

IPCC: The Physical Science Basis. Contribution of Working Group I to the Fourth Assessment Report of the Intergovernmental Panel on Climate Change. Cambridge University Press, New York, USA, available at: http://www.ipcc.ch (last access: 1 March 2011), 2007.

Jacob, D. J., Crawford, J. H., Maring, H., Clarke, A. D., Dibb, J. E., Emmons, L. K., Ferrare, R. A., Hostetler, C. A., Russell, P. B., Singh, H. B., Thompson, A. M., Shaw, G. E., McCauley, E., Pederson, J. R., and Fisher, J. A.: The Arctic Research of the Composition of the Troposphere from Aircraft and Satellites (ARCTAS) mission: design, execution, and first results, Atmos. Chem. Phys., 10, 5191-5212, doi:10.5194/acp-10-5191-2010, 2010.

Jaenicke, R.: Atmospheric aerosols and global climate, J. Aerosol. Sci., 11, 577-588, 1980.

Jimenez, J. L., Canagaratna, M. R., Donahue, N. M., Prevot, A. S. H., Zhang, Q., Kroll, J. H., DeCarlo, P. F., Allan, J. D., Coe, H., Ng, N. L., Aiken, A. C., Docherty, K. S., Ulbrich, I. M., Grieshop, A. P., Robinson, A. L., Duplissy, J., Smith, J. D., Wilson, K. R., Lanz, V. A., Hueglin, C., Sun, Y. L., Tian, J., Laaksonen, A., Raatikainen, T., Rautiainen, J., Vaattovaara, P., Ehn, M., Kulmala, M., Tomlinson, J. M., Collins, D. R., Cubison, M. J., Dunlea, E. J., Huffman, J. A., Onasch, T. B., Alfarra, M. R., Williams, P. I., Bower, K., Kondo, Y., Schneider, J., Drewnick, F., Borrmann, S., Weimer, S., Demerjian, K., Salcedo, D., Cottrell, L., Griffin, R., Takami, A., Miyoshi, T., Hatakeyama, S., Shimono, A., Sun, J. Y., Zhang, Y. M., Dzepina, K., Kimmel, J. R., Sueper, D., Jayne, J. T., Herndon, S. C., Trimborn, A. M., Williams, L. R., Wood, E. C., Middlebrook, A. M., Kolb, C. E., Baltensperger, U., and Worsnop, D. R.: Evolution of organic aerosols in the atmosphere, Science, 326, 1525-1529, doi:10.1126/science.1180353, 2009.

Koch, D. and Hansen, J.: Distant origins of Arctic black carbon: A Goddard Institute for Space Studies ModelE experiment, J.
Geophys. Res., 110, D04204, doi:10.1029/2004jd005296, 2005.

Lavoue, D., Liousse, C., Cachier, H., Stocks, B. J., and Goldammer, J. G.: Modeling of carbonaceous particles emitted by boreal and temperate wildfires at northern latitudes, J. Geophys. Res., 105, 26871-26890, 2000.

Law, K. S. and Stohl, A.: Arctic air pollution: Origins and impacts, Science, 315, 1537-1540, doi:10.1126/science.1137695, 2007.

Lelieveld, J., Berresheim, H., Borrmann, S., Crutzen, P. J., Dentener, F. J., Fischer, H., Feichter, J., Flatau, P. J., Heland, J., Holzinger, R., Korrmann, R., Lawrence, M. G., Levin, Z., Markowicz, K. M., Mihalopoulos, N., Minikin, A., Ramanathan, V., de Reus, M., Roelofs, G. J., Scheeren, H. A., Sciare, J., Schlager, H., Schultz, M., Siegmund, P., Steil, B., Stephanou, E. G., Stier, P., Traub, M., Warneke, C., Williams, J., and Ziereis, H.: Global air pollution crossroads over the Mediterranean, Science, 298, 794-799, 2002.

Li, C., Krotkov, N. A., Dickerson, R. R., Li, Z. Q., Yang, K., and Chin, M.: Transport and evolution of a pollution plume from northern China: A satellite-based case study, J. Geophys. Res., 115, 11, D00k03, doi:10.1029/2009jd012245, 2010.

Lu, Z., Streets, D. G., Zhang, Q., Wang, S., Carmichael, G. R., Cheng, Y. F., Wei, C., Chin, M., Diehl, T., and Tan, Q.: Sulfur dioxide emissions in China and sulfur trends in East Asia since 2000, Atmos. Chem. Phys., 10, 6311-6331, doi:10.5194/acp-106311-2010, 2010.

Matsui, H., Kondo, Y., Moteki, N., Takegawa, N., Sahu, L. K., Zhao, Y., Fuelberg, H. E., Sessions, W. R., Diskin, G., Blake, D. R., Wisthaler, A., and Koike, M.: Seasonal variation of the transport of black carbon aerosol from the Asian continent to the Arctic during the Arctas aircraft campaign, J. Geophys. Res., 116, D05202, doi:05201D.01029/02010JD015067, 2011.

Matthew, B. M., Middlebrook, A. M., and Onasch, T. B.: Collection efficiencies in an aerodyne aerosol mass spectrometer as a function of particle phase for laboratory generated aerosols, Aerosol Sci. Technol., 42, 884-898, doi:10.1080/02786820802356797, 2008.

McConnell, J. R., Edwards, R., Kok, G. L., Flanner, M. G., Zender, C. S., Saltzman, E. S., Banta, J. R., Pasteris, D. R., Carter, M. M., and Kahl, J. D. W.: 20th-century industrial black carbon emissions altered Arctic climate forcing, Science, 317, 1381-1384, doi:10.1126/science.1144856, 2007.

McNaughton, C. S., Clarke, A. D., Howell, S. G., Pinkerton, M., Anderson, B., Thornhill, L., Hudgins, C., Winstead, E., Dibb, J. E., Scheuer, E., and Maring, H.: Results from the DC-8 Inlet Characterization Experiment (DICE): Airborne versus surface sampling of mineral dust and sea salt aerosols, Aerosol Sci. Technol., 41, 136-159, doi:10.1080/02786820601118406, 2007.

Methven, J.: Offline trajectories: Calculations and accuracy, Dept. of Meteorolo., Univ. of Reading, UK, 1997.

Methven, J., Arnold, S. R., O’Connor, F. M., Barjat, H., Dewey, K., Kent, J., and Brough, N.: Estimating photochemically produced ozone throughout a domain using flight data and a lagrangian model, J. Geophys. Res., 108, 4271, doi:10.1029/2002jd002955, 2003.

Mitchell, M.: Visual range in the polar regions with particular reference to the Alaskan Arctic, J. Atmos. Terrestrial Phys., Special Suppl., 17, 195-211, 1956.

Morgan, W. T., Allan, J. D., Bower, K. N., Capes, G., Crosier, J., Williams, P. I., and Coe, H.: Vertical distribution of sub-micron 
aerosol chemical composition from North-Western Europe and the North-East Atlantic, Atmos. Chem. Phys., 9, 5389-5401, doi:10.5194/acp-9-5389-2009, 2009.

Nedelec, P., Cammas, J.-P., Thouret, V., Athier, G., Cousin, J.-M., Legrand, C., Abonnel, C., Lecoeur, F., Cayez, G., and Marizy, C.: An improved infrared carbon monoxide analyser for routine measurements aboard commercial Airbus aircraft: technical validation and first scientific results of the MOZAIC III programme, Atmos. Chem. Phys., 3, 1551-1564, doi:10.5194/acp-3-15512003, 2003.

Neto, T. G. S., Carvalho, J. A., Veras, C. A. G., Alvarado, E. C., Gielow, R., Lincoln, E. N., Christian, T. J., Yokelson, R. J., and Santos, J. C.: Biomass consumption and $\mathrm{CO}_{2}$, $\mathrm{CO}$ and main hydrocarbon gas emissions in an Amazonian forest clearing fire, Atmos. Environ., 43, 438-446, doi:10.1016/j.atmosenv.2008.07.063, 2009.

Ng, N. L., Canagaratna, M. R., Zhang, Q., Jimenez, J. L., Tian, J., Ulbrich, I. M., Kroll, J. H., Docherty, K. S., Chhabra, P. S., Bahreini, R., Murphy, S. M., Seinfeld, J. H., Hildebrandt, L., Donahue, N. M., DeCarlo, P. F., Lanz, V. A., Prévôt, A. S. H., Dinar, E., Rudich, Y., and Worsnop, D. R.: Organic aerosol components observed in Northern Hemispheric datasets from Aerosol Mass Spectrometry, Atmos. Chem. Phys., 10, 46254641, doi:10.5194/acp-10-4625-2010, 2010.

Olivier, J. G. and Berdowski, J. J. M.: Global emissions sources and sinks, in: The climate system, edited by: Berdowski, J., Guicherit, R., and Heij, B. J., A. A. Balkema Publishers/Swets \& Zeitlinger Publishers, Lisse, The Netherlands, 33-78, 2001.

Paris, J.-D., Stohl, A., Nédélec, P., Arshinov, M. Yu., Panchenko, M. V., Shmargunov, V. P., Law, K. S., Belan, B. D., and Ciais, P.: Wildfire smoke in the Siberian Arctic in summer: source characterization and plume evolution from airborne measurements, Atmos. Chem. Phys., 9, 9315-9327, doi:10.5194/acp-9-9315-2009, 2009.

Park, R. J., Jacob, D. J., Palmer, P. I., Clarke, A. D., Weber, R. J., Zondlo, M. A., Eisele, F. L., Bandy, A. R., Thornton, D. C., Sachse, G. W., and Bond, T. C.: Export efficiency of black carbon aerosol in continental outflow: Global implications, J. Geophys. Res.-Atmos., 110, D11205, doi:10.1029/2004jd005432, 2005.

Petzold, A., Weinzierl, B., Huntrieser, H., Stohl, A., Real, E., Cozic, J., Fiebig, M., Hendricks, J., Lauer, A., Law, K., Roiger, A., Schlager, H., and Weingartner, E.: Perturbation of the European free troposphere aerosol by North American forest fire plumes during the ICARTT-ITOP experiment in summer 2004, Atmos. Chem. Phys., 7, 5105-5127, doi:10.5194/acp-7-51052007, 2007.

Quennehen, B., Schwarzenboeck, A., Schmale, J., Stohl, A., Jourdan, O., Ancellet, G., Crummeyrolle, S., and Law K. S.: North American transported pollution plume properties during the POLARCAT summer campaign in Greenland, to be submitted to Atmos. Chem. Phys. Discuss., 2011.

Quinn, P. K., Bates, T. S., Coffman, D., Onasch, T. B., Worsnop, D., Baynard, T., de Gouw, J. A., Goldan, P. D., Kuster, W. C., Williams, E., Roberts, J. M., Lerner, B., Stohl, A., Pettersson, A., and Lovejoy, E. R.: Impacts of sources and aging on submicrometer aerosol properties in the marine boundary layer across the Gulf of Maine, J. Geophys. Res., 111, D23s36, doi:10.1029/2006jd007582, 2006.

Quinn, P. K., Shaw, G., Andrews, E., Dutton, E. G., Ruoho-
Airola, T., and Gong, S. L.: Arctic haze: Current trends and knowledge gaps, Tellus B, 59, 99-114, doi:10.1111/j.16000889.2006.00238.x, 2007.

Quinn, P. K., Bates, T. S., Baum, E., Doubleday, N., Fiore, A. M., Flanner, M., Fridlind, A., Garrett, T. J., Koch, D., Menon, S., Shindell, D., Stohl, A., and Warren, S. G.: Short-lived pollutants in the Arctic: their climate impact and possible mitigation strategies, Atmos. Chem. Phys., 8, 1723-1735, doi:10.5194/acp8-1723-2008, 2008.

Rahn, K. A. and McCaffrey, R. J.: On the origin and transport of the winter Arctic aerosol, Ann. N. Y. Acad. Sci., 388, 486-503, 1980.

Rahn, K. A., Borys, R. D., and Shaw, G. E.: Asian source of Arctic haze bands, Nature, 268, 713-715, 1977.

Reid, J. S., Koppmann, R., Eck, T. F., and Eleuterio, D. P.: A review of biomass burning emissions part II: intensive physical properties of biomass burning particles, Atmos. Chem. Phys., 5, 799825, doi:10.5194/acp-5-799-2005, 2005.

Reitz, P.: Aerosol mass spectrometry on cloud condensation nuclei and ice nuclei, PhD, Fachbereich Physik, Mathematik und Informatik, Johannes Gutenberg-Universität, Mainz, 2011.

Roiger, A., Schlager, H., Schäfler, A., Huntrieser, H., Scheibe, M., Aufmhoff, H., Cooper, O. R., Sodemann, H., Stohl, A., Burkhart, J., Lazzara, M., Schiller, C., Law, K. S., and Arnold, F.: In-situ observation of Asian pollution transported into the Arctic lowermost stratosphere, Atmos. Chem. Phys. Discuss., 11, 1626516310, doi:10.5194/acpd-11-16265-2011, 2011.

Russell, L. M., Hawkins, L. N., Frossard, A. A., Quinn, P. K., and Bates, T. S.: Carbohydrate-like composition of submicron atmospheric particles and their production from ocean bubble bursting, P. Natl. Acad. Sci. USA, 107, 6652-6657, doi:10.1073/pnas.0908905107, 2010.

Schmale, J., Schneider, J., Jurkat, T., Voigt, C., Kalesse, H., Rautenhaus, M., Lichtenstern, M., Schlager, H., Ancellet, G., Arnold, F., Gerding, M., Mattis, I., Wendisch, M., and Borrmann, S.: Aerosol layers from the 2008 eruptions of mount okmok and mount kasatochi: In situ upper troposphere and lower stratosphere measurements of sulfate and organics over europe, J. Geophys. Res., 115, D00L07, doi:10.1029/2009JD013628, 2010.

Schneider, J., Hings, S. S., Hock, B. N., Weimer, S., Borrmann, S., Fiebig, M., Petzold, A., Busen, R., and Karcher, B.: Aircraftbased operation of an aerosol mass spectrometer: Measurements of tropospheric aerosol composition, J. Aerosol. Sci., 37, 839857, doi:10.1016/j.jaerosci.2005.07.002, 2006a.

Schneider, J., Weimer, S., Drewnick, F., Borrmann, S., Helas, G., Gwaze, P., Schmid, O., Andreae, M. O., and Kirchner, U.: Mass spectrometric analysis and aerodynamic properties of various types of combustion-related aerosol particles, Int. J. Mass Spectrom., 258, 37-49, doi:10.1016/j.ijms.2006.07.008, 2006b.

Schnell, R. C.: Arctic haze and the Arctic Gas and Aerosol Sampling Program (agasp), Geophys. Res. Lett., 11, 361-364, 1984.

Shaw, G. E.: The arctic haze phenomenon, B. Am. Meteorol. Soc., 76, 2403-2413, 1995.

Shindell, D. T., Chin, M., Dentener, F., Doherty, R. M., Faluvegi, G., Fiore, A. M., Hess, P., Koch, D. M., MacKenzie, I. A., Sanderson, M. G., Schultz, M. G., Schulz, M., Stevenson, D. S., Teich, H., Textor, C., Wild, O., Bergmann, D. J., Bey, I., Bian, H., Cuvelier, C., Duncan, B. N., Folberth, G., Horowitz, L. W., Jonson, J., Kaminski, J. W., Marmer, E., Park, R., Pringle, 
K. J., Schroeder, S., Szopa, S., Takemura, T., Zeng, G., Keating, T. J., and Zuber, A.: A multi-model assessment of pollution transport to the Arctic, Atmos. Chem. Phys., 8, 5353-5372, doi:10.5194/acp-8-5353-2008, 2008.

Shinozuka, Y., Redemann, J., Livingston, J. M., Russell, P. B., Clarke, A. D., Howell, S. G., Freitag, S., O’Neill, N. T., Reid, E. A., Johnson, R., Ramachandran, S., McNaughton, C. S., Kapustin, V. N., Brekhovskikh, V., Holben, B. N., and McArthur, L. J. B.: Airborne observation of aerosol optical depth during ARCTAS: vertical profiles, inter-comparison and fine-mode fraction, Atmos. Chem. Phys., 11, 3673-3688, doi:10.5194/acp-11-36732011, 2011.

Simoneit, B. R. T., Schauer, J. J., Nolte, C. G., Oros, D. R., Elias, V. O., Fraser, M. P., Rogge, W. F., and Cass, G. R.: Levoglucosan, a tracer for cellulose in biomass burning and atmospheric particles, Atmos. Environ., 33, 173-182, 1999.

Singh, H. B., Anderson, B. E., Brune, W. H., Cai, C., Cohen, R. C., Crawford, J. H., Cubison, M. J., Czech, E. P., Emmons, L., Fuelberg, H. E., Huey, G., Jacob, D. J., Jimenez, J. L., Kaduwela, A., Kondo, Y., Mao, J., Olson, J. R., Sachse, G. W., Vay, S. A., Weinheimer, A., Wennberg, P. O., and Wisthaler, A.: Pollution influences on atmospheric composition and chemistry at high northern latitudes: Boreal and california forest fire emissions, Atmos. Environ., 44, 4553-4563, doi:10.1016/j.atmosenv.2010.08.026, 2010 .

Sodemann, H., Pommier, M., Arnold, S. R., Monks, S. A., Stebel, K., Burkhart, J. F., Hair, J. W., Diskin, G. S., Clerbaux, C., Coheur, P.-F., Hurtmans, D., Schlager, H., Blechschmidt, A.-M., Kristjánsson, J. E., and Stohl, A.: Episodes of cross-polar transport in the Arctic troposphere during July 2008 as seen from models, satellite, and aircraft observations, Atmos. Chem. Phys., 11, 3631-3651, doi:10.5194/acp-11-3631-2011, 2011.

Spackman, J. R., Schwarz, J. P., Gao, R. S., Watts, L. A., Thomson, D. S., Fahey, D. W., Holloway, J. S., de Gouw, J. A., Trainer, M., and Ryerson, T. B.: Empirical correlations between black carbon aerosol and carbon monoxide in the lower and middle troposphere, Geophys. Res. Lett., 35, L19816, doi:10.1029/2008g1035237, 2008.

Stocks, B. J., Mason, J. A., Todd, J. B., Bosch, E. M., Wotton, B. M., Amiro, B. D., Flannigan, M. D., Hirsch, G. K., Logan, K. A., Martell, D. L., and Skinner, W. R.: Large forest fires in Canada, 1959-1997, J. Geophys. Res., 108, 8149, doi:10.1029/2001JD000484, 2002.

Stohl, A.: A 1-year lagrangian "climatology" of airstreams in the Northern Hemisphere troposphere and lowermost stratosphere, J. Geophys. Res., 106, 7263-7279, 2001.

Stohl, A.: Characteristics of atmospheric transport into the Arctic troposphere, J. Geophys. Res., 111, 17, D11306, doi:10.1029/2005jd006888, 2006.

Stohl, A., Forster, C., Eckhardt, S., Spichtinger, N., Huntrieser, H., Heland, J., Schlager, H., Wilhelm, S., Arnold, F., and Cooper, O.: A backward modeling study of intercontinental pollution transport using aircraft measurements, J. Geophys. Res., 108, 4370, doi:10.1029/2002jd002862, 2003.

Stohl, A., Forster, C., Frank, A., Seibert, P., and Wotawa, G.: Technical note: The Lagrangian particle dispersion model FLEXPART version 6.2, Atmos. Chem. Phys., 5, 2461-2474, doi:10.5194/acp-5-2461-2005, 2005.

Stohl, A., Andrews, E., Burkhart, J. F., Forster, C., Herber, A.,
Hoch, S. W., Kowal, D., Lunder, C., Mefford, T., Ogren, J. A., Sharma, S., Spichtinger, N., Stebel, K., Stone, R., Strom, J., Torseth, K., Wehrli, C., and Yttri, K. E.: Pan-arctic enhancements of light absorbing aerosol concentrations due to North American boreal forest fires during summer 2004, J. Geophys. Res., 111, D22214, doi:10.1029/2006jd007216, 2006.

Stohl, A., Berg, T., Burkhart, J. F., Fjæraa, A. M., Forster, C., Herber, A., Hov, Ø., Lunder, C., McMillan, W. W., Oltmans, S., Shiobara, M., Simpson, D., Solberg, S., Stebel, K., Ström, J., Tørseth, K., Treffeisen, R., Virkkunen, K., and Yttri, K. E.: Arctic smoke - record high air pollution levels in the European Arctic due to agricultural fires in Eastern Europe in spring 2006, Atmos. Chem. Phys., 7, 511-534, doi:10.5194/acp-7-511-2007, 2007.

Streets, D. G., Bond, T. C., Carmichael, G. R., Fernandes, S. D., Fu, Q., He, D., Klimont, Z., Nelson, S. M., Tsai, N. Y., Wang, M. Q., Woo, J. H., and Yarber, K. F.: An inventory of gaseous and primary aerosol emissions in Asia in the year 2000, J. Geophys. Res., 108, 8809, doi:10.1029/2002jd003093, 2003.

Talbot, R. W., Vijgen, A. S., and Harriss, R. C.: Soluble species in the Arctic summer troposphere - acidic gases, aerosols, and precipitation, J. Geophys. Res., 97, 16531-16543, 1992.

van der Werf, G. R., Randerson, J. T., Giglio, L., Collatz, G. J., Kasibhatla, P. S., and Arellano Jr., A. F.: Interannual variability in global biomass burning emissions from 1997 to 2004, Atmos. Chem. Phys., 6, 3423-3441, doi:10.5194/acp-6-3423-2006, 2006.

Villani, P., Picard, D., Marchand, N., and Laj, P.: Design and validation of a 6-volatility tandem differential mobility analyzer (VTDMA), Aerosol Sci. Technol., 41, 898-906, doi:10.1080/02786820701534593, 2007.

Voigt, C., Schumann, U., Jurkat, T., Schäuble, D., Schlager, H., Petzold, A., Gayet, J.-F., Krämer, M., Schneider, J., Borrmann, S., Schmale, J., Jessberger, P., Hamburger, T., Lichtenstern, M., Scheibe, M., Gourbeyre, C., Meyer, J., Kübbeler, M., Frey, W., Kalesse, H., Butler, T., Lawrence, M. G., Holzäpfel, F., Arnold, F., Wendisch, M., Döpelheuer, A., Gottschaldt, K., Baumann, R., Zöger, M., Sölch, I., Rautenhaus, M., and Dörnbrack, A.: In-situ observations of young contrails - overview and selected results from the CONCERT campaign, Atmos. Chem. Phys., 10, 90399056, doi:10.5194/acp-10-9039-2010, 2010.

von Schneidemesser, E., Schauer, J. J., Hagler, G. S. W., and Bergin, M. H.: Concentrations and sources of carbonaceous aerosol in the atmosphere of Summit, Greenland, Atmos. Environ., 43, 4155-4162, doi:10.1016/j.atmosenv.2009.05.043, 2009.

Warneke, C., Froyd, K. D., Brioude, J., Bahreini, R., Brock, C. A., Cozic, J., De Gouw, J. A., Fahey, D. W., Ferrare, R., Holloway, J. S., Middlebrook, A. M., Miller, L., Montzka, S., Schwarz, J. P., Sodemann, H., Spackman, J. R., and Stohl, A.: An important contribution to springtime Arctic aerosol from biomass burning in Russia, Geophys. Res. Lett., 37, L01801, doi:10.1029/2009GL041816, 2010.

Wernli, H. and Davies, H. C.: A lagrangian-based analysis of extratropical cyclones .1. The method and some applications, Q. J. Roy. Meteorol. Soc., 123, 467-489, 1997.

Wiedinmyer, C., Quayle, B., Geron, C., Belote, A., McKenzie, D., Zhang, X. Y., O'Neill, S., and Wynne, K. K.: Estimating emissions from fires in North America for air quality modeling, Atmos. Environ., 40, 3419-3432, 
doi:10.1016/j.atmosenv.2006.02.010, 2006.

Yokelson, R. J., Crounse, J. D., DeCarlo, P. F., Karl, T., Urbanski, S., Atlas, E., Campos, T., Shinozuka, Y., Kapustin, V., Clarke, A. D., Weinheimer, A., Knapp, D. J., Montzka, D. D., Holloway, J., Weibring, P., Flocke, F., Zheng, W., Toohey, D., Wennberg, P. O., Wiedinmyer, C., Mauldin, L., Fried, A., Richter, D., Walega, J., Jimenez, J. L., Adachi, K., Buseck, P. R., Hall, S. R., and Shetter, R.: Emissions from biomass burning in the Yucatan, Atmos. Chem. Phys., 9, 5785-5812, doi:10.5194/acp-9-5785-2009, 2009.
Zhang, Q., Streets, D. G., Carmichael, G. R., He, K. B., Huo, H., Kannari, A., Klimont, Z., Park, I. S., Reddy, S., Fu, J. S., Chen, D., Duan, L., Lei, Y., Wang, L. T., and Yao, Z. L.: Asian emissions in 2006 for the NASA INTEX-B mission, Atmos. Chem. Phys., 9, 5131-5153, doi:10.5194/acp-9-5131-2009, 2009. 